\title{
Mobil Telefon Kullanıcılarının Mobil Bağımlılık Durumu ve 5G Teknolojisi Kabullenme Niyeti Modellerinin Geliştirilmesi Araştırma Makalesi/Research Article
}

\author{
(iD) Ayşe ÖZDUMAN ${ }^{1}$, (D) Başak GÖK ${ }^{2}$, (D) Hadi GÖKÇEN ${ }^{3}$ \\ ${ }^{1}$ Network Performans Ölçüm Sistemleri Birimi, Türk Telekomünikasyon A.Ş., Ankara, Türkiye \\ ${ }^{2}$ Bilgi İșlem Daire Başkanlığı, Gazi Üniversitesi, Ankara, Türkiye \\ ${ }^{3}$ Endüstri Mühendisliği Bölümü, Gazi Üniversitesi, Ankara, Türkiye \\ ayseozduman2@gmail.com, basakgok@gazi.edu.tr, hgokcen@gazi.edu.tr \\ (Geliş/Received:09.04.2019; Kabul/Accepted:18.06.2020) \\ DOI: $10.17671 /$ gazibtd. 551198
}

\begin{abstract}
Özet- Teknolojinin hızla geliştiği son yıllarda kablonun sınırlarından kurtulma ve aynı anda kablosuz birçok cihaza bağlanma isteği yeni teknolojilerin geliştirilmesine neden olmuştur. Mobil telefonlar, bilgisayar ile yapılabilecek her türlü işlemi gerçekleştirebilme olanağı sağlamanın yanında zeki özellikleri ile internete erişim imkânı sağlaması sayesinde toplumda en çok kullanılan teknolojik cihazlar haline gelmiştir. Mobil telefonların aşırı kullanımı toplumda mobil bağımlılı̆̆ın ortaya çıkmasına neden olmuştur. Toplumun mobil telefon kullanırken çoklu ortamda (ses, video, oyun, vb.) yüksek kapasite (bant genişliği) ve düşük gecikme ihtiyacı yeni nesil teknolojilerin geliştirilmesini gerektirmektedir. Bu araştırmada telekomünikasyon şirketi çalışanlarının mobil telefon bağımlılık durumları ve yeni geliştirilen $5 \mathrm{G}$ teknolojisini kabullenme niyetleri belirlenerek değerlendirme yapılmıștır. Uygulanan anket çalışması ile elde edilen verilerin yapısal geçerliliği doğrulayıcı faktör analizi ile test edilerek, mobil bağımlılık ve $5 \mathrm{G}$ teknolojisi kabullenme niyeti arasındaki ilişki regresyon analizi ile belirlenmiştir. Araştırmada mobil bağımlılık ve $5 \mathrm{G}$ teknolojisi kabullenme niyeti arasında pozitif yönde ilişki olduğu bulunmuştur.
\end{abstract}

Anahtar Kelimeler - mobil bağımlılık, teknoloji kabullenme niyeti, 5g

\section{Mobile Addiction Status of Mobile Phone Users and Development of 5G Technology Acceptance Intention Models}

\begin{abstract}
In the recent years that technology grows up rapidly, the desire to get rid of limitation of cables and the wish of to be able to connect more than one wireless network simultaneously caused new technological developments come to life. The mobile phones became the most used technological devices by providing the ability of doing every process that computers can do and besides providing the internet access with their smart properties. The excessive usage of mobile phones make an addiction in society. The necessity of the society to the high capacity (bandwidth) and low latency while using mobile phones with multimedia (voice, video, game etc.) requires new technologies to be developed. By this investigation; the mobile phone addiction status and the new-developed 5G technology acceptance intention of the employees of a telecommunication company are determined and evaluated. By the survey implemented, structural validity of the obtained data is tested with confirmatory factor analyses and so the relation between mobile addiction and the newdeveloped 5G technology acceptance intention is identified with by regression analysis. In this investigation a positive relationship is found between mobile addiction and the new-developed 5G technology acceptance intention.
\end{abstract}

Keywords - mobile addiction, technology acceptance intention, $5 \mathrm{~g}$

Dipnot: Mobil Telefon Kullanıcılarının Mobil Bă̆ımlılık Durumu ve 5 G Teknolojisi Kabullenme Niyeti Modellerinin Geliştirilmesi Bitirme Projesi, Prof. Dr. Hadi Gökçen, Gazi Üniversitesi, Bilişim Enstitüsü, Ocak 2019. 


\section{GİRIŞ (INTRODUCTION)}

Bilişim teknolojileri insan hayatının her alanında yaşamı kolaylaştırmayı, toplumu şekillendirmeyi, bireylerin davranışlarında etkiler bırakmayı başarmıştır. Kablonun sınırlarından kurtulma ve aynı anda kablosuz birçok cihaza bağlanma isteği yeni teknolojilerin geliştirilmesine neden olmuştur. Gelişen mobil teknolojiler de bu isteklerin daha da artmasını sağlamıştır. Mobil telefonların, bilgisayarla yapılabilecek birçok işlemi gerçekleştirebilmenin yanında, zeki özellikleri ile internete erişim imkânı sağlaması, onları toplumda en çok kullanılan teknolojik cihazlar haline getirmiştir. Mobil telefonlarla birçok işlemin yapılması, kullanım süresini artırmakta, bu durum da bireylerde mobil bağımlılığın oluşmasına sebep olmaktadır. Geçmişte bağımlılık sadece alkol, sigara, uyuşturucu gibi madde bağımlılıkları olarak bilinirken, artık teknoloji ve teknolojik cihazlara olan bağımlılık da eklenmiştir [31].

Sosyal ağlar üzerinden mesajlaşma, yüksek çözünürlüklü fotoğraf ve video paylaşımı, mobil cihazlar ile yüksek boyutlu öğrenim materyallerine ulaşma [37], yazılı ve sesli haberleşmede öne çıkan mobil uygulamalar [36] ve mobil uygulama ile oynanan çevrim içi oyunlar gibi birçok alanda internet kullanımı giderek artmaktadır. Mobil telefonların kullanım alanlarının artması daha yüksek bant genişliği, kapasite ve iletim hızı ihtiyacını ortaya çıkararak yeni nesil teknolojilere talebi artıracaktır.

$\mathrm{Bu}$ araştırmada mobil telefon kullanıcılarının mobil bağımlılık durumları ve yeni geliştirilen $5 \mathrm{G}$ teknolojisini kabullenme niyetleri arasındaki ilişkinin incelenmesi amaçlanmaktadır. Araştırmada, katılımcıların mobil bağımlılık durumları ve yeni geliştirilen $5 \mathrm{G}$ teknolojisini kabullenme niyetlerine ilişkin veri anket ile toplanmıştır. Anket sonuçları doğrulayıcı faktör analizleri ile test edilerek, regresyon ile model hakkında ayrıntıl değerlendirme yapılmıştır. Araştırma Türkiye'de, bir telekomünikasyon şirketi çalışanları ile sınırlandırılmıştır.

Araştırma kapsamında mobil teknolojiler, 5G teknolojisi, teknolojik bağımlılık konularında literatür çalışmalarına yer verilmiştir. Mobil bağımlılık durumu ve yeni teknolojilerin kabullenme niyetleri toplumlara ve zamana göre farklılık göstereceğinden sürekli olarak araştırması önem arz etmektedir. 5G teknolojisi hem dünya hem de ülkemizin gündeminde olan çok yeni bir teknoloji olması nedeniyle, bu teknolojinin kabullenilmesine yönelik tutum ve davranışların incelenmesi literatüre katkı sağlaması sebebiyle önemlidir.

2. MOBİL TEKNOLOJI, 5G TEKNOLOJISİ VE BAĞIMLILIK (MOBILE TECHNOLOGY, 5G TECHNOLOGY AND ADDICTION)

\subsection{Mobil Teknoloji (Mobile Technology)}

Kablosuz telefon ilk olarak Martin Cooper tarafindan 1973 yılında geliştirilmiştir. Bununla birlikte kabloların sınırlarından kurtulabilme fikri, iletişimde dünyanın odak noktası olmuştur [9]. 1983 yılında mobil ilk görüşme yapılmıştır ve mobil telefonların kullanımları hızla artmıştır. Daha sonra 1994'de IBM'ın zeki telefon üretimiyle mobil telefonların kullanımında yeni bir dönem başlamıştır [24].

Son y1llarda ise Ericson'un 2018 Haziran ayında yayınladığ 1 Mobility Report'da dünya genelindeki mobil abone sayısı sekiz milyardır [12]. Bilgi Teknolojileri Kurumu (BTK)'nun 2018 yılı ikinci çeyrekte yayınladığı Üç Aylık Pazar Verileri Raporu'nda Türkiye'de \%98,4 penetrasyon (nüfusa olan oran) oranı ile 79.5 milyon mobil abone bulunmaktadır. Toplam gerçekleșen mobil internet kullanım miktarı 730.744 TB'tır. 2018 ikinci çeyreğinde toplam gerçekleşen mobil trafik hacmi 67,7 milyar dakikadır. 2018 ikinci çeyrek trafik bilgileri 2018 birinci çeyrek ile karşılaştırıldığında toplam mobil trafik \%5,9 oranında artmıştır, 2017 ikinci çeyrek ile karşılaştırıldığında ise \%6 oranında arttığı görülmektedir [10]. Türkiye İstatistik Kurumu (TÜİK) 2018 Hanehalkı Bilişim Teknolojileri (BT) Kullanım Araştırması'na göre, nisan ayında genişbant ile internet erişimi sağlayan hane oran1 \%82,5'tir. Hanelerden \%44,5'i sabit (xDSL, fiber, kablolu internet vb.) genişbant ile erişirken, \%79,4'ü mobil genişbant ile internet erişimi sağlamaktadır. 2017 yılında ise, genişbant internet erişim imkânına sahip hane oranı $\% 78,3$ 'tü, hanelerin \%40'1 sabit, \%72,4'ü mobil genişbant bağlantı ile internet erișimi sağlamıștır [17]. Global System for Mobile Communications Association (GSMA) tarafindan hazırlanan Intelligence The Mobile Economy 2018 verileri ve tahminlerine göre 2017 yılında tüm bağlantıların \%57'sini zeki telefonlar oluştururken 2025 yılında bu oranın \%77 olması beklenilmektedir [13].

Türkiye'de, tüm bu değerler göz önüne alındığında, hem mobil kullanıcı sayısının hem de mobil internet bağlantı oranının oldukça yüksek olduğu ve her geçen gün daha da arttığ1 görülmektedir.

\subsection{Mobil Teknoloji Tarihsel Gelișimi (Historical \\ Development of Mobile Technology)}

İlk kablosuz telefonun 1973 yılında bulunmasıyla başlayan mobil teknoloji, 1983 y1lında İngilizcesi generation olan birinci nesil adı ile adlandırılan $1 \mathrm{G}$ olarak isimlendirilmiştir.

Mobil haberleşmenin kitlelere yayılması $1 \mathrm{G}$ ile ilk olarak Amerika'da başlamıştır. Birinci nesil haberleşme (1G), AMPS (Advanced Mobile Phone System) teknolojisi ile ses iletiminde hücre yapısı getirilmiştir. Ancak iletim altyapısının analog olması nedeniyle zamanla kurulan ulusal şebekeler birbiriyle uyumlu olarak çalışamamıştır. 1983-1991 yılları arasında, 2G (ikinci generation) ile uluslararası uyum sağlayan standartlar geliştirilmiş ve roaming (uluslararası dolaşım) altyapısı kullanılmıştır. 2G ile küresel mobil bir şebekeden bahsedilebilir, $2 \mathrm{G}$ şebekesi dijital veri iletimi olanakları sayesinde mobil veri iletimini sağlamaktadır. Kullanıcı cihazları (mobil telefon vb.) ve mobil iletişim altyapısında yer alan, dijital sinyal işleme ve ileri yönlü hata düzeltme teknolojilerinin maliyetlerinin ve satış ücretlerinin azalması, 2G'nin ticarileşmesinin en temel tetikleyicisi olmuştur. $\mathrm{Bu}$ nesilde, Avrupa'nın kurduğu GSM (Global System for Mobile 
Communications) teknolojisi bütün dünyada liderliği elde etmiştir. GSM ile ses ve veri, dünyanın birçok yerinde sorunsuz ve uyumlu bir şekilde dolaşmaktadır. 2001 yılında, Avrupa'nın UMTS (Universal Mobile Telecommunications System) standardı ve uluslararası standartların belirleyiciliği üzerine inşa edilen $3 \mathrm{G}$ (üçüncü generation) ile küresel başarı sağlanmıştır. 2010 yılında kullanıcılar, kurumlar ve telekomünikasyon pazarı üreticilerine göre $3 \mathrm{G}$ bazı uygulamalarda yetersiz kalmaya başlamıştır. Bu nedenle yeni bir nesil olarak 4G (dördüncü generation) Long Term Evolution (LTE), onu izleyen 4.5G Long Term Evolution Advanced (LTE-Advanced) standardı üzerine inşa edilmiştir [15]. 4.5G dördüncü nesil teknolojidir, $4 \mathrm{G}$ içerisinde değerlendirilmektedir.

\begin{tabular}{|c|c|c|c|c|c|c|}
\hline 1973 & 1983 & 1991 & 1994 & 2001 & 10 & 2020 \\
\hline \multirow[t]{2}{*}{ Illk kablosuz telefon } & & $\begin{array}{c}2 G^{\prime} \text { ye geçiş ve ilk SMS } \\
\text { in atılması }\end{array}$ & & $\begin{array}{l}\text { 3G'ye geçiş ve ilk } \\
\text { görüntülü arama }\end{array}$ & $4.5 \mathrm{G}$ & 5G'ye geçiş \\
\hline & $\begin{array}{l}1 \mathrm{G} \text { ve ilk mobil } \\
\text { görüşme }\end{array}$ & & $\begin{array}{l}\text { Illk zeki telefonun } \\
\text { üretilmesi }\end{array}$ & & & \\
\hline
\end{tabular}

Şekil 2.1. Mobil teknoloji tarihsel gelişimi

(Historical development of mobile technology)

$1 \mathrm{G}$ ile ilk yurtiçi sesli görüşmenin yapılmasıyla başlayan mobil teknoloji, 2G'de uluslararası sesli görüşme ve mesaj iletimi ile devam etmiştir. $3 \mathrm{G}$ teknolojisiyle ilk görüntülü görüşme sağlanarak, $4 \mathrm{G}$ ve $4.5 \mathrm{G}$ teknolojileri ile çok daha hızlı ve kaliteli servisler sağlayan teknolojilerine geçilmiştir.
2020 yılında veri trafiğinin artması ve bu trafiğin \% $75^{\prime}$ inin video olması beklenmektedir [1]. Bu durum daha gelişmiş yeni iletim teknolojisi ihtiyacını doğurmaktadır. 5G (beşinci generation) olarak adlandırılan yeni teknolojide 10 Gbps veri iletim hızı ile bant genişliğinin artırılması ve 1 ms'nin altında düşük gecikmenin sağlanması planlanmaktadır.

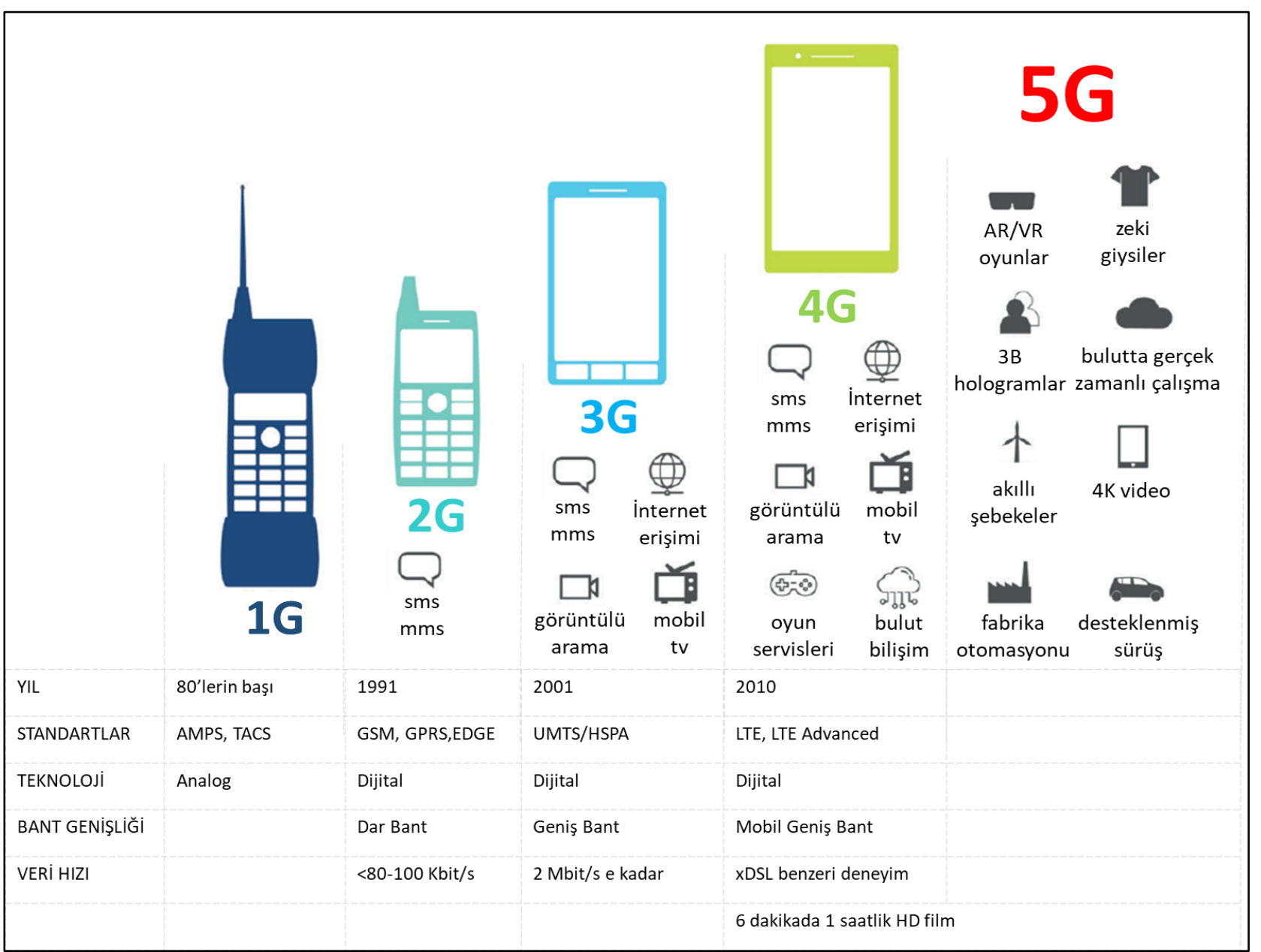

Şekil 2.2. Mobil teknolojiler [19]

(Mobile Technologies) 


\subsection{G Teknolojisi ve Kullanım Deneyimleri (5G Technology and Usage Experiences)}

Haberleşmenin insan hayatındaki rolü, gelişen her yeni teknolojide dijitalleşme ile daha fazla artmaktadır. 5G, haberleşme teknolojisinde tarafları "insandan insana", "insandan makineye" ve "makineden insana" şeklinde kullanımın ilerisine götürmeyi hedeflemektedir. 5G'nin esas vaadi mobil hizmet ve uygulamaların yükselen ihtiyacını karşılayabilmek ve haberleşme teknolojisini yaşamın tüm alanlarına yayarak "tüm nesnelere" haberleşme kabiliyeti kazandırmaktır [19].

5G'nin getireceği yeni özellikler şunlardır.

Yüksek Hiz: Verinin indirilmesi ve yüklenmesi ile oluşan veri aktarım miktarıdır. 5G teknolojisinde veri iletim hızı 10 Gbps ve üzeri olarak planlanmaktadır. $5 \mathrm{G}$ ile gigabit ve üstündeki hızlar ile ultra yüksek (8K) çözünürlükteki içeriklere ulaşılabilir ve sanal gerçeklik uygulamaları kullanabilir. Yüksek hıza sahip bu teknoloji yüksek hıza gereksinim duyan mobil bulut servislerinin önünü açacaktır.

Düşük Gecikme: Veri iletiminde yaşanan gecikme süresinin en aza indirilmesi yeni teknolojilerin beklentileri arasındadır. Ağdaki gecikmelerin 5G ile $1 \mathrm{~ms}$ 'nin altında tutularak, uzaktan araç haberleşmesi ve gerçek zamanlı mobil kontrolü uygulamalarının gerçekleşmesi planlanmaktadır.

Yüksek Kapasite: Kapasite verinin hacmi ile ilișkili olup, bant genişliğinde yüksek miktarda verinin aktarılmasını sağlar. $5 \mathrm{G}$ ile $6 \mathrm{GHz}$ altında $100 \mathrm{MHz}, 6 \mathrm{GHz}$ üstünde 400 $\mathrm{MHz}$ kanal bant genişliği sağlanacaktır. $5 \mathrm{G}$ ile sağlanan yüksek kapasite ile 100 milyar cihaza sürekli ulaşılacaktır. Günümüzde kullandığımız 4,5G teknolojisine göre 1000 kat yüksek kapasitede birim alanı kapsayacaktır.

Enerji Verimliliği: Verimlilik, sistemin kullandığı enerji ile sisteme verilen enerji oranı olup, pil ömrünün uzatılmasını ve verilen enerji ile en fazla işi yapmayı amaçlar. Enerji verimliliğinde yaklaşık 1000 kata ulaşan iyileştirmeler ve cihazların pil sorunlarının azaltılması beklenmektedir. Minimum on yıl pil ömrü bulunan sensörler hedeflenmektedir [19].

Yüksek Coğrafi Kapsama ve Erişim: Küçük ve çok sayıda baz istasyonu ile kapsama alanın artırılması ve daha geniş coğrafi alanda hizmet verilebilmesidir. 5G için zorunlu olan kesintisiz bağlantı ve coğrafi kapsama, ekonomik getiri ve iş planlarının artmasına olanak sağlayacaktır.

Ayrıca veri trafiği 50 Exabyte/ay, 100 milyon bağlantı $/ \mathrm{km}^{2}$, \%99.999 kullanılabilirlik ve güvenirlik sağlayacaktır [19].

5G, devletlerin, düzenleyici kurumların ve endüstrinin ortaklaşa yaratacağı bir fikir birliği ile ilerlemektedir. Uluslararası Telekomünikasyon Birliği (ITU) 5G'nin yüksek kapasite ve hızın sağlanacağı Gelişmiş Mobil Geniş Bant, yüz milyarlarca makinenin haberleşeceği Masif Makine Haberleşmesi, otomasyonda Ultra Güvenlik ve Düşük Gecikme olmak üzere üç temel yapı üzerine kurulmakta olduğunu bildirmektedir [14].

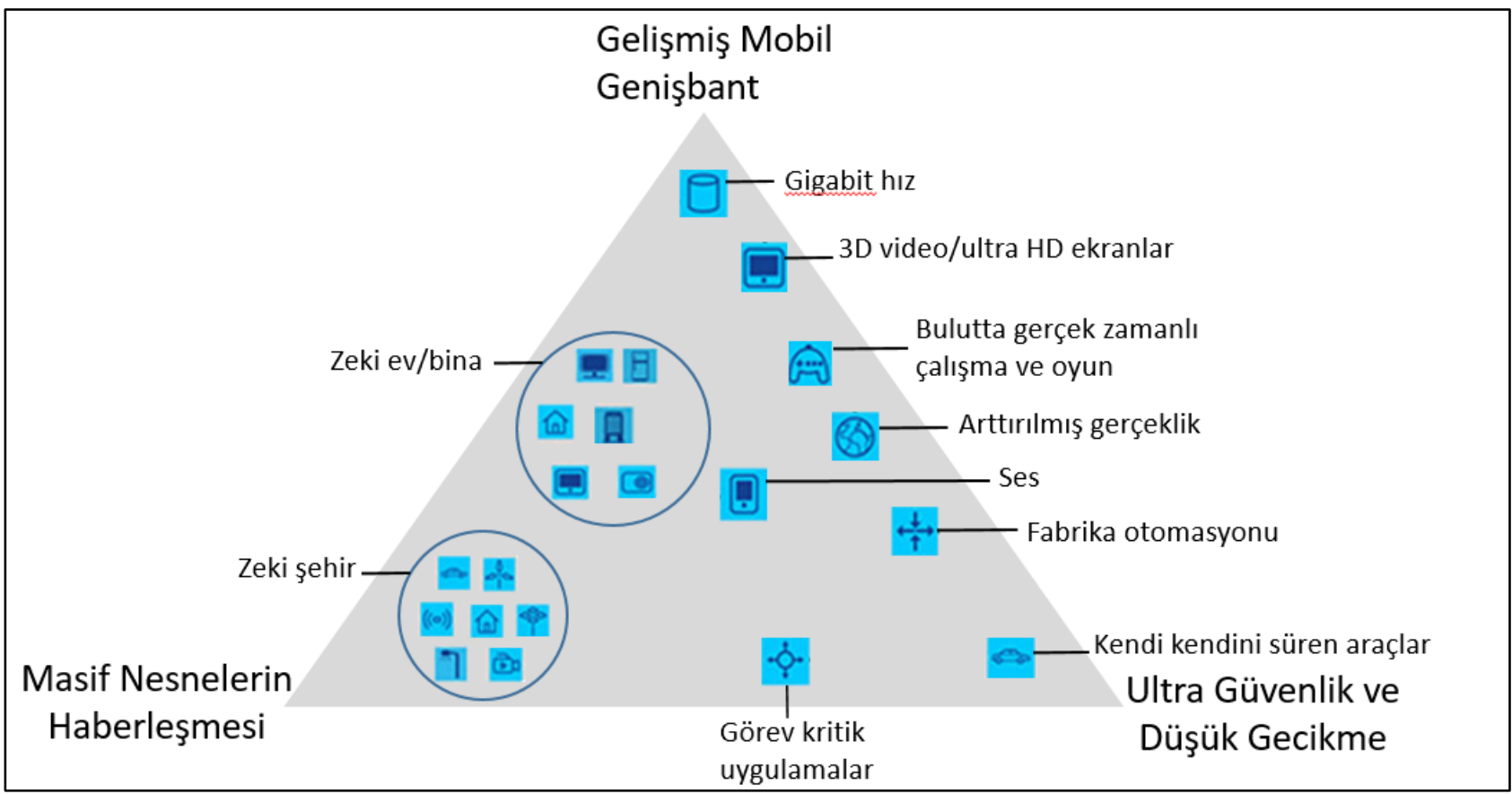

Şekil 2.3. ITU IMT-2020 (5G) [14]

(ITU IMT-2020 (5G)) 
Pazar araştırması şirketi Ovum 2018 yılı ikinci çeyreğinde yayınladığı raporda, dünyadaki operatörlerin $5 \mathrm{G}$ teknolojisine geçiş yıllarını bildirmektedir [16].

Tablo 2.1. Dünyadaki operatörlerin 5G’ye geçiş tarihleri [16]

(5G transition dates of operators in the world)

\begin{tabular}{|l|l|l|l|}
\hline \multicolumn{1}{|c|}{$\mathbf{2 0 1 8}$} & \multicolumn{1}{|c|}{$\mathbf{2 0 1 9}$} & \multicolumn{2}{|c|}{$\mathbf{2 0 2 0}$} \\
\hline AT\&T & $\begin{array}{l}\text { China Mobile } \\
\text { (China) }\end{array}$ & $\begin{array}{l}\text { China Telecom } \\
\text { (China) }\end{array}$ & Salt (Switzerland) \\
\hline $\begin{array}{l}\text { Swisscom } \\
\text { (Switzerland) }\end{array}$ & Du (UAE) & $\begin{array}{l}\text { China Unicom } \\
\text { (China) }\end{array}$ & Softbank (Lapan) \\
\hline $\begin{array}{l}\text { Verizon } \\
\text { (USA)v }\end{array}$ & $\begin{array}{l}\text { KT (South } \\
\text { Korea) }\end{array}$ & $\begin{array}{l}\text { Chunghwa } \\
\text { (Taiwan) }\end{array}$ & $\begin{array}{l}\text { Sunrise } \\
\text { (Switzerland) }\end{array}$ \\
\hline & $\begin{array}{l}\text { Optus } \\
\text { (Australia) }\end{array}$ & $\begin{array}{l}\text { Deutsche } \\
\text { Telekom } \\
\text { (Multiple) }\end{array}$ & $\begin{array}{l}\text { Tele2/Telenor } \\
\text { (Sweden) }\end{array}$ \\
\hline & $\begin{array}{l}\text { SKT (South } \\
\text { Korea) }\end{array}$ & $\begin{array}{l}\text { DoCoMo } \\
\text { (Japan) }\end{array}$ & $\begin{array}{l}\text { Telia (Sweden, } \\
\text { Finland, Estinia) }\end{array}$ \\
\hline & Sprint (USA) & $\begin{array}{l}\text { FarEastone } \\
\text { (Taiwan) }\end{array}$ & Telstra (Australia) \\
\hline & $\begin{array}{l}\text { STC (Suudi } \\
\text { Arabia) }\end{array}$ & $\begin{array}{l}\text { HKT (Hong } \\
\text { Kong) }\end{array}$ & TIM (Italy) \\
Mobile & $\begin{array}{l}\text { Taiwan) } \\
\text { (USA) }\end{array}$ & $\begin{array}{l}\text { Orange } \\
\text { (Multiple) }\end{array}$ & $\begin{array}{l}\text { Vodafone (New } \\
\text { Zealand, Multiple) }\end{array}$ \\
\hline
\end{tabular}

5G teknolojisi ile sağlık, ulaşım, otomotiv, tarım, enerji, medya ve eğlence, zeki şehir ve zeki ev gibi birçok alanda yeni teknolojilerin hayata geçirilmesi beklenmektedir.

Sağlıkta; uzaktan sağlık hizmeti ile muayene, uzaktan tanı ve görüntüleme ile tıbbi vaka teşhisi, yardımlı ameliyat ile bir cerrahın başka bir cerrahı uzaktan yönlendirmesi, uzaktan ameliyat ile bir cerrahın bir robotu uzaktan yönlendirmesi ve giyilebilir giysi ile sağlık durumu görüntüleme.

Ulaşım ve otomotivde; yardımlı sürüş ile sürücüye gerçek zamanlı bilgi verme, Otonom/İşbirlikli sürüş (V2XVehicle to Everything, Araçtan Her şeye) ile sürücü fonksiyonlarını aracın devralması, uzaktan kontrollü sürüş ile aracı sürücüsüz uzaktan kullanma.

Havacılıkta; Dron deneyimi ile askeri alanda haberleşme, Tarımda; su yönetimi, gübreleme, hayvancılık, sondaj, tohumlama ve püskürtme, havadan ürün izleme, veri odaklı tarım ile sensörler, uzaktan kontrol ve kumanda sistemleri, otonom tarım makineleri ile traktörler, ekim aletleri, birbiri ile konuşan tüm alet ve makinelerin senkron olarak yönetilmesi.

Enerjide; zeki elektrik ve zeki aydınlatma sistemleri ile anlık izleme, zeki şehir, zeki ev, zeki fabrika.

Medya ve ĕglencede; $4 \mathrm{~K}$ dan $8 \mathrm{~K}$ TV'ye geçiş ile yüksek çözünürlük, oyunlar, güvenlik kameraları, artırılmış gerçeklik ve sanal gerçeklik uygulamaları alanlarında kullanılması beklenmektedir [11].

\subsection{Teknolojik ve Mobil Bă̆ımlılık (Technological and Mobile Addiction)}

Bağımlılık kavramı, birçok kişi tarafından alkol ve uyuşturucu madde kullanımı olarak özdeşleştirilmektedir [8]. Bağımlılık, davranışa yönelik bağımlılıklar (yemeiçme, kumar, spor, teknoloji, internet, mobil cihaz) ve madde bağımlılıkları (sigara, uyuşturucu, alkol) olmak üzere iki tipte tanımlanmaktadır.

Davranışa yönelik bağımlılıklardan teknoloji bağımlılığı, bilişim teknolojilerinden doğan bir problemdir ve teknolojik aygıtlarının aşırı kullanımıyla ortaya çıkan zihinsel bir durumdur [31]. Teknoloji [8] ve internet kullanımı [35] bu davranışlar arasında kabul edilmektedir. Kişilerin kontrolünü kaybetmesine sebep olarak bağımlılık riskini arttırmaktadır.

Zeki telefonlar, davranışsal ve bilişsel gelişimde olumlu etkilere sahip olduğu gibi beraberinde birçok sorunu da getirmektedir [23]. Bu sorunlardan birisi, psikolojik ve zorlayıcı davranışların neden olduğu strestir. Bireylerin zeki telefon bağımlılığı sosyal etkileşim kaygısı, zorunlu kullanım, kontrol odağı ve dokunma gereksinimi boyutlarında incelenmiş, sosyal etkileşim kaygısının bireylerin günlük yaşamlarını olumsuz etkilediği gözlemlenmiştir [23].

Mobil bağımlılık ise teknolojik bağımlılık içerisinde geçen davranışa yönelik bir bağımlılıktır. Davranışsal bir rahatsızlık olarak değerlendirilen bu bağımlılık durumu, bireylerin mobil cihazları aşırı kullanma arzusu, mobil cihazlara dokunma hissinin verdiği haz, mobil cihazlar ile etkileşim sağlandığında sosyal kaygıyı yok etme isteği gibi nedenlerden kaynaklanmaktadır [23].

İlk teknolojik bağımlılık ölçeği Young [35] tarafından geliştirilmiştir. Choliz [3], mobil bağımlılı̆̆ tolerans, yoksunluk ve kontrol eksikliği faktörleriyle açıklanmıştır. Young [35] ve Choliz [3] internet bağımlılık ölçeğini geliştirdikten sonra Kwon, Lee, Won, Park, Min, Hahn, $\mathrm{Gu}$, Choi [22] ve Kim [20] ise mobil bağımlılık ölçeğini geliştirmişlerdir. Mobil bağımlılık, tolerans, uzaklaşım, gündelik yaşama ait bozukluk, sanal ilişki, gereğinden fazla kullanma ve pozitif beklentiden oluşan 6 boyut ile ifade edilebileceğini belirtmişlerdir. Çalışma kapsamında mobil bağımlılık eğitim düzeyi ve meslek grubu arasında anlamlı farkların bulunduğu, cinsiyetle ilişkili olmadığ gözlenmiştir [22]. Kwon vd. [22] ergenlere yönelik mobil bağımlılık ölçeği geliştirmişlerdir. Kwon vd. [22] geliştirdiği Mobil Bă̆ımlılık Ölçeği, Türkçe diline çevrilip üniversite öğrencileri üzerinde uygulanmıştır, güvenilir ve geçerli bulunduğu belirtilmiştir [5]. Demirci, Orhan, Demirdaş, Akpınar ve Sert'in [5] Türkçeye uyarladığı ölçek, Young'ın [35] internet ölçeğiyle beraber kullanılarak üniversite öğrencilerinde uygulanmış, mobil bağımlılık ve internet bağımlılığının pozitif ilişkisi bulunduğu bulgusuna ulaşılmıştır [25]. Kim, Lee, Nam, Chung lise öğrencilerinin mobil bağımlılı̆̆ını adaptasyon bozukluğu, sanal yaşam oryantasyonu, uzaklaşım ve toleranstan oluşan dört faktörlü bir Zeki Telefon Bağımlılık Ölçeği geliştirerek geçerli ve güvenilir bulunmuştur [20]. 
Bağımlılık kavramı genelde duygusal değişim, çatışma, tolerans, belirginlik, uzaklaşım ve tekrarlama şeklinde altı faktörle açıklanmaktadır [21]. Türkiye'deki mobil internet kullanımları ve mobil bağımlılık ile ilgili çalışmalar yer almaktadır. Ayrıca araştırmalarda örneklem olarak öğrencilerin seçildiği gözlemlenmiştir [7]. Zeki telefonların günlük hayatta kullanımının artması, zeki telefondan mahrum kalma (çevrimiçi olamama ve haberleşememe) korkusu olarak ifade edilen Nomofobi (No Mobile Phone Phobia, Nomophobia) olgusunun ortaya çıkmasına neden olmuştur. Erdem, Türen ve Kalkın [6] mobil telefondan yoksun olma korkusunun (nomofobi) yayılması Türkiye'deki üniversite öğrencileri ve kamu çalışanları örnekleminde incelemiştir ve öğrencilerin \%54'ünün, kamu çalışanlarının ise \%47'sinin nomofobik olduğunu belirlemiştir. Ayrıca kadınlardaki nomofobinin erkeklerden daha yüksek olduğu, nomofobi ve yaş arasında anlamlı ve ters yönlü bir ilişki bulunduğu, nomofobi ve zeki telefon günlük kullanım süresiyle arasında anlamlı ve pozitif yönde bir ilişki olduğu bulunmuştur [6].

Fidan [7] mobil bağımlılı̆̆ı inceleyen çalışmaları araştırarak, mobil bağımlılık ölçeğini oluşturan bileşenlerin duygusal değişim, belirginlik, tolerans, çatışma, uzaklaşım ve tekrarlama olduğunu belirtmiştir.

i. Duygusal değişim: Eylemin bireylerde değişik zamanlarda değişik ruhsal durum meydana getirmesidir. Uyanır uyanmaz sigara içmeye hevesli sigara bağımlısı, yatmadan sigara içmeyi istememesi ve neredeyse sigara içmekten nefret etmesi.

ii. Belirginlik: Eylemin, bireylerin yaşamında en önemli etkinlik olması bireyin duygu, düşünce ve tavırlarını baskı altına almasıdır. Bir kişinin sigara tiryakisi olması ve sigara içemeyeceği için uçak seyahati yapmayı istememesi.

iii. Tolerans: Bağımlı olunan nesne, amaç, durum kullanımının giderek artmasıdır. Uyku bağımlılığı olan bir kişinin, uykunun verdiği haz nedeniyle günlük uyuma süresini daha da artırmasıdır. Spor yapmaya bağımlı olan birinin, sağlıklı vücudu olması için günlük yaptığı sporu biraz daha artırması da toleransa örnek verilebilir.

iv. Çatışma: Kişide bulunan bağımlılığın kişinin çevresinde bulunan kişiler ve kendi içinde çatışma yaşamasına neden olmasıdır. Bilgisayarda oyun oynama bağımlılı̆̆ bulunan bir kişinin hem ailesi hem de sosyal çevresiyle sorunlar yaşaması durumudur.

v. Uzaklaşım: Bağımlı olunan nesne, amaç, durum kullanımın kesilmesi ya da azaltılmasıyla kişide psikolojik veya fiziksel sorunların meydana gelmesidir. Örneğin yemek yeme bağımlılığı olan bir kişinin, yemek yemeyi azalttıktan sonra sinirli, huzursuz olması, ellerinde titremelerin ve uyuşmaların başlaması gibi problemlerin görülmesi durumudur.

vi. Tekrarlama: Bağımlılığın, bir kişi tarafindan uzun bir süre kullanımına ara verilmesine rağmen daha sonra tekrar başlamasıdır. Sigara bağımlısı bir kişinin sigarayı bıraktıktan sonra, birkaç sigara içtikten sonra, daha önce sigarayı hiç bırakmamış gibi yeniden sigara içmeye devam etmesi durumu örnek verilebilir. vii. Mobil internet ĕ̌ilimi: Mobil internet kullanımını sevme, isteme ya da yapmaya içten yönelmedir.

\subsection{G Teknolojisi Kabullenme Niyeti (5G Technology Acceptance Intention)}

İnternete bağlı her cihazın bir internet protokol (ip) adresi bulunmaktadır. Sapakal [29], teknolojinin artık ip tabanlı kullanıma gittiğini, kullanıcıların birden fazla kablosuz teknolojiye aynı anda bağlanması ve aralarında geçiş yapabileceği bir teknolojiye ihtiyaç duyduğunu, bunun da 5G ile sağlanabileceğini vurgulamaktadır. Patil ve Wankhade [28] çalışmalarında, kablosuz teknolojinin nesillere göre nasıl geliştiğini, gelecekte neden daha gelişmiş 5G teknolojisi kullanmak gerektiğini, network (ağ) mimarisini göstererek açıklamaktadır. 5G teknolojisin geçmiş teknolojilere göre daha düşük maliyetli genişbant kablosuz bağlantı sağladığını belirtilmiştir [28].

Serçemeli ve Kurnaz [30] bilgi teknoloji ürünleri kullanımına yönelik eğilim sebeplerinin, Teknoloji Kabul Modeli (TKM) aracılığıyla açıklanması amacıyla TKM'nde algılanan kullanım kolaylığı, algılanan fayda, kullanımına yönelik tutum, davranışa yönelik niyet ve gerçekleşen davranış faktörlerinin arasında bulunan ilişskiyi değerlendirmek için bir anket çalışması yapmıştır. Sonuç olarak, bilgi teknolojileri ürünlerinin kullanımına yönelik algılanan fayda ve niyet eğilimlerinin oldukça yüksek olduğu görülmüştür [30]. Çelik, Yılmaz ve Pazaroğlu [4] Teknoloji Kabul Modeli (TKM) ile e-alışverişe yönelik tüketici davranışlarını belirleyen faktörler arasındaki ilişkiyi yapısal eşitlik modellemesi yaparak açıklamıştır. Mobil uygulama kabul modelini esasına dayanan çalışmada güvenirliği ve geçerliliği fazla bir mobil uygulama kabullenme ölçeği oluşturulmuştur [32]. Xu, Thong ve Tam [33] 2G mobil internet teknolojisini bırakanların $3 \mathrm{G}$ teknolojisi çıktığında onu kullanma niyetini Teknoloji Kullanımını Bırakanları Geri Kazanma: Mobil Internet Hizmetleri Konusunda Teknolojiyi Yeniden Kullanma (Kabullenme) Modeli Testi ile değerlendirmiştir. 2G'yi kullanmayı bırakanların 3G'yi yeniden kullanma niyetleri, algılanan fiyat değeri, algılanan üstünlük, çaba beklentisi, sosyal etki ve kabullenme niyeti ile pozitif yönlü etki göstermiştir [33].

2G'den 3G'ye geçişte $2 \mathrm{G}$ mobil internet teknolojisini bırakanların $3 \mathrm{G}$ teknolojisi çıktığında onu yeniden kullanma niyetini inceleyen $\mathrm{Xu}$ vd. [33] ise yeni teknoloji olan $3 \mathrm{G}$ kabullenme niyeti bileşenlerini, algılanan fiyat değeri, algılanan üstünlük, çaba beklentisi, sosyal etki ve kabullenme niyeti ile açıklamıştır.

i. Kabullenme Niyeti: Yeni teknolojiyi benimsemeye ilişkin tutumdur.

ii. Algllanan Üstünlük: Teknolojiyi kullanma sonucunda kişide ortaya çıkan ihtiyacının giderilme kalitesi yani fayda algisidır.

iii. Algllanan Fiyat Değeri: Bireyde teknolojinin ya da ürünün fiyat ile ekonomik değeri arasındaki değer algisıdir.

iv. Çaba Beklentisi: Teknolojinin sunduğu servislerin kullanım kolaylığını gösterir. 
v. Sosyal Etki: Sosyal çevresindeki kişilerin bireyde bıraktığı etkilerdir.

\section{YÖNTEM, ANALIZZ VE BULGULAR (METHOD,} ANALYSIS AND FINDINGS)

\subsection{Yöntem (Methods)}

Bu çalışmada Türkiye'deki bir telekomünikasyon şirketi çalışanlarının mobil bağımlılık durumu ve $5 \mathrm{G}$ teknolojisi kabullenme niyeti arasındaki ilişkiyi araştırmak için anket yapılmıştır. Anketlerin güvenilirliği araştırılmış ve doğrulayıcı faktör analizi (DFA) ile yapı geçerliliği sınanmıştır. Mobil bağımlılık durumu ile 5G teknolojisi kabullenme niyeti arasındaki ilişki regresyon analizi ile belirlenmiştir.

\subsection{Evren ve Örneklem (Universe and Sample)}

Mobil telefon kullanan telekomünikasyon sektörü çalışanları bu çalışmanın evrenini oluşturmaktadır. Örneklem, Türkiye'nin farklı yedi bölgesine ait illerde bir telekomünikasyon şirketinde çalışan kişilerden oluşmaktadır. Telekomünikasyon şirketi çalışanlarının örneklem olarak seçilmesinin nedeni hem mobil telefon kullanımı hem de yeni çıkacak 5G teknolojisi hakkında daha fazla ön bilgiye sahip olmalarıdır.

Evreni temsil eden örneklem tabakalı örnekleme yöntemiyle seçilmiştir.

Tabakall örnekleme, evrenin daha fazla temsil edilmesini sağlamak amacıyla örnekleme hatasını azaltan bir seçim yöntemidir. $\mathrm{Bu}$ yöntemde, örnekleme hatasını azaltmak için, büyük bir evrene ihtiyaç vardır ve evrenden çekilen örneklemin çok sayıda olması gerekmektedir. Çok fazla sayıda örneklem ile çalışılamadığı zaman homojen evrenleri kullanmak gerekir. Tabakalı örnekleme yönteminin temel prensibi homojen bir evren oluşturmaktır. Orantılı ve orantısız olmak üzere iki çeşit tabakalı örnekleme yöntemi vardır. Orantısız yöntemde, tabakalardan seçilen örneklemin sayısı belirlenir, sonrasında tabakaların örneklemin içerisindeki bulunma oranı göz ardı edilir ve eşit sayılarda örnekler seçilip değerlendirilir. Seçilmiş örneklemin evreni temsil etme kabiliyeti sınırlıdır ve evren içinde bulunan tabakaların bu örneklemde anlamlı bir büyüklükte temsil edilmesinin gerekmesi durumlarında kullanılmaktadır. Orantıl yöntemde, tabakalardan, o tabakanın evrendeki temsil seviyesiyle orant1lı olan örneklemi belirtilir ve bu örneklemin evreni tamamen temsili için örneklem içerisindeki farklı grupların örnekleme oranının, evrendeki ile aynı olması sağlanır [2].

Çalışmada Türkiye coğrafi bölgeleri tabaka olarak alınmıştır. Her bölgeden nüfus ile orantılı olacak sayıda anket değerlendirilmiştir. Nüfus verilerinin coğrafi bölgelere göre dağılımı TÜİK 2017 y1lı temel istatistikleri üzerinden belirlenmiştir [18]. Telekomünikasyon sektörü çalışanları oranı da nüfus dağılım oranı ile benzer özellik göstermektedir.
Tablo 3.1. Nüfusa göre örneklem alınan anket sayısı (Number of questionnaires sampled by population)

\begin{tabular}{|l|c|c|c|}
\hline Bölge & Toplam Nüfus & Oran & Anket Sayıs \\
\hline Akdeniz & 10303984 & $13 \%$ & 56 \\
\hline Doğu Anadolu & 5686905 & $7 \%$ & 31 \\
\hline Ege & 10383963 & $13 \%$ & 57 \\
\hline Güneydoğu Anadolu & 8940926 & $11 \%$ & 49 \\
\hline İç Anadolu & 12895988 & $16 \%$ & 71 \\
\hline Karadeniz & 7405126 & $9 \%$ & 41 \\
\hline Marmara & 25193633 & $31 \%$ & 138 \\
\hline Genel Toplam & 80810525 & $100 \%$ & 443 \\
\hline
\end{tabular}

\section{Varsayım ve Sinırlılıklar}

Araştırmada katılımcıların anket sorularına içten ve doğru cevap verdikleri varsayılmıştır. Araştırma örnekleminin tüm evreni temsil edeceği varsayımı kabul edilmiştir. Araştırmanın yapıldığı örneklem grubunun sadece Türkiye'de olması, anketin uygulandığ çalışmanın sınırlılıklarıdır.

\subsection{Veri Toplama Aracı ve Verilerin Toplanması (Data Collection Tool and Data Collection)}

Araştırmada, veri toplama aracı olarak Fidan'ın [7] geliştirdiği "Mobil bağımlılık ölçeğii" ve Xu vd. [33] geliştirdiği "5G teknolojisi kabullenme niyeti" ölçeklerinden yararlanılmıştır. Fidan [7] tarafından geliştirilmiş "Mobil bağımlılık ölçeği" geçerlik ve güvenilirliği test edilmiş bir ölçme aracıdır. Kullanıcıların mobil bağımlılıklarını ölçme amacıyla hazırlanmış 28 maddeli, 5'li likert yapıdadır. Ölçek belirginlik, duygusal değişim, tolerans, uzaklaşım, çatışma, tekrarlama, mobil internet eğilimi boyutlarıyla mobil bağımlılı̆̆ açıklamaktadır. Mobil bağımlılık ölçeğinin hazırlanmasında Fidan [7] Griffiths [8], Young [35], Choliz [3], Kwon vd. [22], Kuss vd. [21], tarafindan geliştirilen ölçeklerden yararlanmıştır ve bu ölçek kullanılmıştır. 5G teknolojisini kabullenme niyeti ise $\mathrm{Xu}$ vd. [33] tarafından geliştirilen $3 \mathrm{G}$ teknolojisini kullanma niyeti ölçeğinden yararlanılarak ölçülmüştür. $\mathrm{Xu}$ vd. $2 \mathrm{G}$ teknolojisini kullanmayı bırakanların 3G'ye geçişlerini incelemiştir. Bu çalışmadaki 2G'den 3G'ye geçişteki tüm maddeler, 4G'den 5G'ye geçiş şeklinde güncellenerek düzenlenmiştir. Ölçek kabullenme niyeti, algılanan üstünlük, algılanan fiyat, çaba beklentisi, sosyal etki boyutlarından oluşup, 7'li likert yapıdadır. Bu ölçekteki tüm 2G'den 3G'ye geçiş ifadeleri 4G'den 5G'ye geçiş ifadesi olarak düzenlenerek 20 maddeli, 5'li likert yapıda uygulama yapılmıştır. Veri toplamada kullanılan ölçeklere ait maddelerin bulunduğu faktörler ve referanslar EK-1'de yer almaktadır.

Araştırmada kullanılan anket, demografik bilgiler, mobil bağımlılık ölçeği ve 5G teknolojisi kabullenme niyeti ölçeği olmak üzere üç bölümden oluşmaktadır. Ankette, yaş, cinsiyet, il, ilçe, medeni durum, eğitim durumu, çalışılan alan, çalışılan pozisyon, kullanılan işletim sistemi, 
kullanılan teknoloji, kullanım yılı ve günlük kullanım süresi olmak üzere 12 demografik değişkenler ve mobil internet servisleri kullanımına ilişkin 3'lü likert türünde yedi soru yer almaktadır (Bkz. EK-2). Mobil bağımlılık durumu için 5'li likert türünde yedi faktörden oluşan 28 soru ve $5 \mathrm{G}$ teknolojisi kabullenme niyeti için yönlendirilen 5'li likert türünde beş faktörden oluşan 20 soru bulunmaktadır (Bkz. EK-2). Anket soruları online anket sistemi (www.surveey.com) üzerinden hazırlanarak eposta aracılığıyla katılımcılar ile paylaşılmıştır. Anket tamamen gönüllük esasına dayalı olarak yapılmış olup kişisel bilgiler gizlilik ilkesine bağlı olarak korunmuştur. Gönüllü katılımcıların yanıtları değerlendirilmiştir.

Veriler 2018 yılı kasım ve aralık aylarında 35 gün içerisinde toplanmıştır. Anket soruları 1000 kişiye gönderilmiştir. 450 tamamlanmış, 176 tamamlanmamış toplam 626 adet anket formu yanıtlanmıştır, tamamlanmayan anketler değerlendirmeye alınmamıştır. Veri kümesine göre uç değer olarak gözlenen yedi anket çıkartılarak, toplamda 443 anket yanıtı değerlendirilmiştir.

\subsection{Verilerin Analizi (Data Analysis)}

Veri analizinde IBM SPSS Statistics 21 ve AMOS 21 programlarından yararlanılmıştır. Analizde kullanılan mobil bağımlılık ve $5 \mathrm{G}$ teknolojisi kabullenme niyeti verilerinin normal dağılıma uygunluğu, basıklık ve çarpıklığı araştırılmıştır. Güvenilirlik Cronbach's Alpha katsayısı değerleri ile karşılaştırılmıştır. Verilerin analizinde katılımcılara ait betimsel istatistikler frekans ve yüzdelerle sunulmuştur.

Araştırma katılımcılarına ait demografik değişkenlerin (yaş, cinsiyet, medeni durum, eğitim düzeyi, çalışılan alan ve pozisyon, kullanılan işletim sistemi ve teknoloji) dağılımını içeren betimsel istatistikler Tablo 3.2'de ve ankette yer alan mobil telefonun günlük kullanım amacı ile ilgili yönlendirilen sorulara verilen cevaplara ilişkin istatistikler Tablo 3.3'te verilmiştir.

Tablo 3.2. Demografik değişkenlerin istatistiksel dağılımı

(Statistical distribution of demographic variables)

\begin{tabular}{|c|c|c|c|c|c|}
\hline & & Frekans & Yüzde & $\begin{array}{l}\text { Geçerli } \\
\text { yüzde }\end{array}$ & $\begin{array}{l}\text { Toplam } \\
\text { yüzde }\end{array}$ \\
\hline \multirow[t]{3}{*}{ Cinsiyet } & Erkek & 255 & 57,6 & 57,6 & 57,6 \\
\hline & Kadın & 188 & 42,4 & 42,4 & 100,0 \\
\hline & Total & 443 & 100,0 & 100,0 & \\
\hline \multirow[t]{3}{*}{ Medeni Durum } & Evli & 314 & 70,9 & 70,9 & 70,9 \\
\hline & Bekar & 129 & 29,1 & 29,1 & 100,0 \\
\hline & Total & 443 & 100,0 & 100,0 & \\
\hline \multirow[t]{4}{*}{ Yaş } & $20-30$ & 133 & 30,0 & 30,0 & 30,0 \\
\hline & $30-40$ & 249 & 56,2 & 56,2 & 86,2 \\
\hline & $40-51$ & 42 & 9,5 & 9,5 & 100,0 \\
\hline & Total & 443 & 100,0 & 100,0 & \\
\hline \multirow[t]{5}{*}{ Eğitim Düzeyi } & Ortaöğretim & 2 & 0,5 & 0,5 & 0,5 \\
\hline & Önlisans & 77 & 17,4 & 17,4 & 17,8 \\
\hline & Lisans & 260 & 58,7 & 58,7 & 76,5 \\
\hline & Lisansüstü & 104 & 23,5 & 23,5 & 100,0 \\
\hline & Total & 443 & 100,0 & 100,0 & \\
\hline \multirow[t]{3}{*}{ Çalışılan Alan } & Teknik & 283 & 63,9 & 63,9 & 63,9 \\
\hline & Ticari & 160 & 36,1 & 36,1 & 100,0 \\
\hline & Total & 443 & 100,0 & 100,0 & \\
\hline \multirow[t]{7}{*}{ Çalıșılan Pozisyon } & Teknik-Ticari-Destek Personeli & 88 & 19,9 & 19,9 & 19,9 \\
\hline & Uzman Yard.-Mühendis-Uzman-Yetkili-Temsilci & 159 & 35,9 & 35,9 & 55,8 \\
\hline & $\begin{array}{l}\text { Ekip Yöneticileri-Kıdemli Uzmanlar-Proje Yöneticileri- } \\
\text { Eksperler }\end{array}$ & 132 & 29,8 & 29,8 & 85,6 \\
\hline & $\begin{array}{l}\text { Teknik-Ticari-Destek Departman Müdürü-Grup Müdürü- } \\
\text { İl/İlçe Müdürü }\end{array}$ & 61 & 13,8 & 13,8 & 99,3 \\
\hline & $\begin{array}{l}\text { Direktör-Teknik-Ticari-Destek Bölge Müdür Yardımcısı- } \\
\text { Bölge Müdürü-Genel Müdür }\end{array}$ & 2 & 0,5 & 0,5 & 99,8 \\
\hline & Diğer & 1 & 0,2 & 0,2 & 100,0 \\
\hline & Total & 443 & 100,0 & 100,0 & \\
\hline \multirow[t]{3}{*}{ İşletim Sistemi } & iOS & 256 & 57,8 & 57,8 & 57,8 \\
\hline & Android & 187 & 42,2 & 42,2 & 100,0 \\
\hline & Total & 443 & 100,0 & 100,0 & \\
\hline \multirow[t]{3}{*}{ Teknoloji } & $3 \mathrm{G}$ & 35 & 7,9 & 7,9 & 7,9 \\
\hline & $4 \mathrm{G}-4.5 \mathrm{G}$ & 408 & 92,1 & 92,1 & 100,0 \\
\hline & Total & 443 & 100,0 & 100,0 & \\
\hline
\end{tabular}


Tablo 3.3. Mobil telefonun günlük kullanım amacı istatistikleri

\begin{tabular}{|l|l|l|l|l|l|l|c|}
\hline & \multicolumn{2}{|c|}{ Asla } & \multicolumn{2}{c|}{ Nadiren } & \multicolumn{2}{c|}{ Günde birçok defa } & Toplam \\
\hline SMS & 24 & $5,4 \%$ & 379 & $85,6 \%$ & 40 & $9,0 \%$ & 443 \\
\hline MMS & 401 & $90,5 \%$ & 41 & $9,3 \%$ & 1 & $0,2 \%$ & 443 \\
\hline Zil sesi ve logo yüklemeleri & 385 & $86,9 \%$ & 57 & $12,9 \%$ & 1 & $0,2 \%$ & 443 \\
\hline Mobil oyunlar & 155 & $35,0 \%$ & 221 & $49,9 \%$ & 67 & $15,1 \%$ & 443 \\
\hline Web sitelerini taramak & 3 & $0,7 \%$ & 21 & $4,7 \%$ & 419 & $94,6 \%$ & 443 \\
\hline Mobil e-posta & 0 & $0,00 \%$ & 11 & $2,5 \%$ & 432 & $97,5 \%$ & 443 \\
\hline Mobil uygulamalar & 5 & $1,1 \%$ & 31 & $7,00 \%$ & 407 & $91,9 \%$ & 443 \\
\hline
\end{tabular}

Analizde kullanılan mobil bağımlılık ve $5 \mathrm{G}$ teknolojisi kabullenme niyeti verilerinin normal dağılıma uygunluğu, basıklık ve çarpıklığı araştırılarak Şekil 3.1 ve 3.2 'de sunulmuştur.

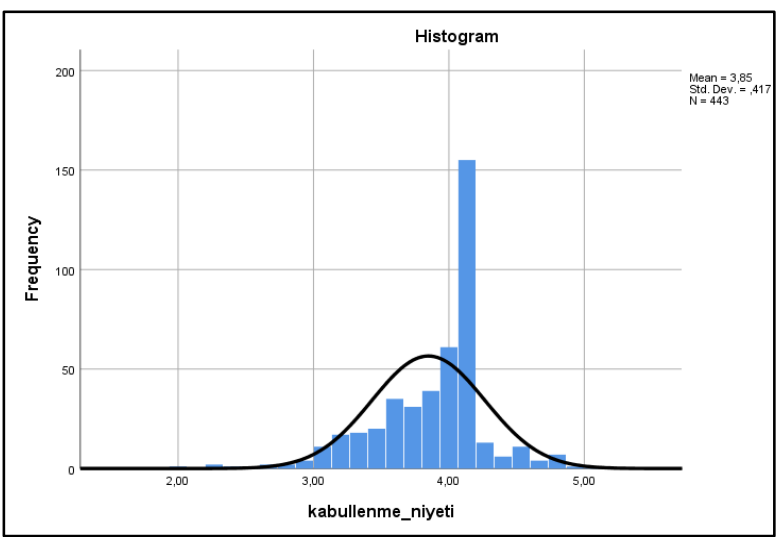

Şekil 3.1. 5G teknolojisi kabullenme niyeti normal dağılım grafiği

(5G technology acceptance intention normal distribution graph)

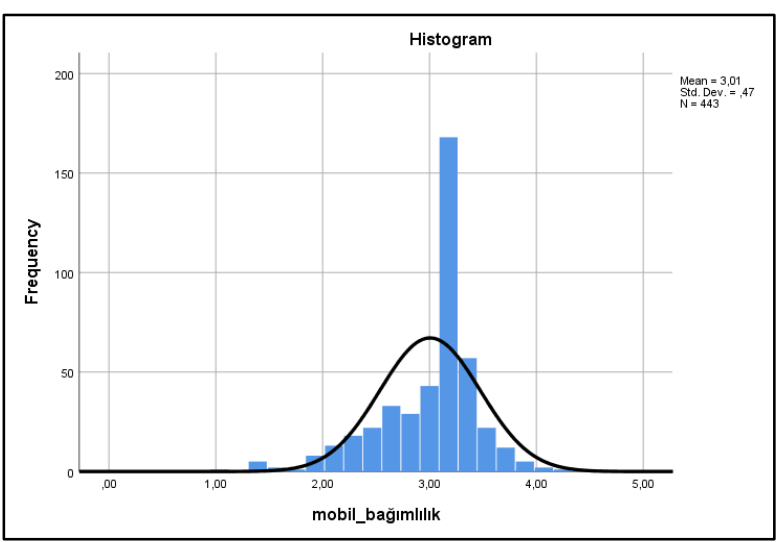

Şekil 3.2. Mobil bağımlılık durumu normal dağılım grafiği

(Mobile addiction status normal distribution graph)
Veri kümesinin normal dağılım gösterdiği, basıklık ve çarpıklık değerlerinin kabul edilebilir seviyede olduğu görülmüştür. Güvenilirlik Cronbach's Alpha katsayısı değerleri ile karşılaştırılmış ve Tablo 3.4'te sunulmuştur.

Tablo 3.4. Güvenilirlik

(Reliability values)

\begin{tabular}{|l|l|}
\hline \multicolumn{2}{|l|}{ Ölçme aracıCronbach's Alpha } \\
\hline Mobil bağımlılık & 0,913 \\
\hline 5G kabullenme niyeti & 0,890 \\
\hline Mobil bağımlılık & Cronbach's Alpha \\
\hline Tolerans(T) & 0,826 \\
\hline Tekrarlama(TE) & 0,792 \\
\hline Mobil internet eğilimi(I) & 0,771 \\
\hline Duygusal değişim(D) & 0,751 \\
\hline Uzaklaşım(U) & 0,732 \\
\hline Çatışma(C) & 0,730 \\
\hline Belirginlik(B) & 0,715 \\
\hline 5G kabullenme niyeti & Cronbach's Alpha \\
\hline Sosyal etki(SE) & 0,961 \\
\hline Çaba beklentisi(CB) & 0,943 \\
\hline Algılanan fiyat(AF) & 0,929 \\
\hline Algılanan üstünlük(AU) & 0,846 \\
\hline Kabullenme niyeti(KN) & 0,728 \\
\hline
\end{tabular}

Mobil bağımlılık ve 5G kabullenme niyeti güvenilirlik katsayısı Cronbach's Alpha değeri sirasıyla 0,913 ve 0,890 olarak tespit edilmiş ve bileşen değişkenlerinin güvenilirlik katsayıları da kabul edilebilir değerlerdedir.

\subsection{Bulgular (Findings)}

Mobil bağımlılık durumu ve $5 \mathrm{G}$ teknolojisi kabullenme niyetine demografik değişkenlerin etkileri, normal dağılım gösteren iki grubun tek değişkene göre birbirinden farkını bulmak için cinsiyet ve medeni durum değişkenleri sınıflama türü T-testi ile araştırılmıştır. Normal dağılım gösteren üç veya daha fazla grubun tek değişkene göre karşılaştırmasını bulmak için yaş, eğitim durumu, çalışılan pozisyon değişken sınıflama türü One-way Anova testi ile incelenmiştir. 
Tablo 3.5. T-testi sonuçları

\begin{tabular}{|c|c|c|c|c|c|c|c|c|c|}
\hline & $\mathbf{F}$ & $\mathbf{p}$ & $\mathbf{t}$ & df & $\begin{array}{l}\text { İki } \\
\text { yönlü } \\
\text { p }\end{array}$ & $\begin{array}{l}\text { Ortalama } \\
\text { farklar }\end{array}$ & $\begin{array}{l}\text { Farkların } \\
\text { standart } \\
\text { hatası }\end{array}$ & $\begin{array}{l}\text { Farkların } \\
\text { aralığı } \\
\text { Alt }\end{array}$ & $\begin{array}{ll}5 \% & \text { güven } \\
\text { Üst } & \end{array}$ \\
\hline \multirow{2}{*}{$\begin{array}{l}\text { Mobil_bağımlılık } \\
\text { cinsiyet }\end{array}$} & 24,328 & 0,000 & $-2,672$ & 441 & 0,008 & $-0,11989$ & 0,04486 & $-0,20806$ & $-0,03172$ \\
\hline & & & $-2,805$ & 440,735 & 0,005 & $-0,11989$ & 0,04274 & $-0,20389$ & $-0,03588$ \\
\hline \multirow{2}{*}{$\begin{array}{l}\text { Mobil_bağımlılık } \\
\text { medeñi durum }\end{array}$} & 3,502 & 0,062 & $-0,728$ & 441 & 0,467 & $-0,03580$ & 0,04917 & $-0,13244$ & 0,06084 \\
\hline & & & $-0,786$ & 284,361 & 0,432 & $-0,03580$ & 0,04554 & $-0,12544$ & 0,05384 \\
\hline \multirow{2}{*}{$\begin{array}{l}\text { 5G kabullenme_niyeti } \\
\text { cinsiyet }\end{array}$} & 19,037 & 0,000 & $-0,754$ & 441 & 0,451 & $-0,02552$ & 0,03385 & $-0,09205$ & 0,04101 \\
\hline & & & $-0,795$ & 439,303 & 0,427 & $-0,02552$ & 0,03208 & $-0,08858$ & 0,03754 \\
\hline \multirow{2}{*}{$\begin{array}{l}\text { 5G kabullenme_niyeti } \\
\text { medeni durum }\end{array}$} & 0,013 & 0,909 & $-0,074$ & 441 & 0,941 & $-0,00273$ & 0,03685 & $-0,07515$ & 0,06969 \\
\hline & & & $-0,076$ & 252,863 & 0,939 & $-0,00273$ & 0,03588 & $-0,07339$ & 0,06792 \\
\hline
\end{tabular}

Mobil bağımlılık durumunun demografik değişkenler için T-testi sonuçlarına göre mobil bağımlılık durumu cinsiyet değişkenine göre istatistiksel olarak anlamlı fark gözlenirken $(p<0.05)$, medeni durum değişkenine göre istatistiksel olarak anlamlı fark gözlenmemektedir (p>0.05). Ortalama değerlerine bakıldığında kadınların erkeklerden mobil bağımlılık düzeyinin daha yüksek olduğu görülmektedir. Cinsiyet ve medeni durum değişkenlerinin 5G teknolojisi kabullenme niyeti üzerinde istatistiksel olarak anlamlı etkisi bulunmamaktadır $(\mathrm{p}<0.05)$.

Tablo 3.6. One-way Anova varyans analizi testi sonuçları

(One-way Anova variance analysis test results)

\begin{tabular}{|c|c|c|c|c|c|c|}
\hline & \multicolumn{6}{|l|}{ ANOVA } \\
\hline & & Kareler toplamı & $\mathrm{df}$ & Kareler ortalaması & $\mathrm{F}$ & $\mathrm{p}$ \\
\hline \multirow{3}{*}{$\begin{array}{l}\text { Mobil_bağımlılık } \\
\text { yaş }\end{array}$} & Gruplararası & 14,319 & 30 & 0,477 & 2,361 & 0,000 \\
\hline & Gruplariçi & 83,288 & 412 & 0,202 & & \\
\hline & Toplam & 97,607 & 442 & & & \\
\hline \multirow{3}{*}{$\begin{array}{l}\text { Mobil_bağımlılık } \\
\text { eğitim durumu }\end{array}$} & Gruplararas1 & 0,925 & 3 & 0,308 & 1,400 & 0,242 \\
\hline & Gruplariçi & 96,682 & 439 & 0,220 & & \\
\hline & Toplam & 97,607 & 442 & & & \\
\hline \multirow{3}{*}{$\begin{array}{l}\text { Mobil_bağımlılık } \\
\text { çalışılan alan }\end{array}$} & Gruplararası & 2,408 & 1 & 2,408 & 11,153 & 0,001 \\
\hline & Gruplariçi & 95,200 & 441 & 0,216 & & \\
\hline & Toplam & 97,607 & 442 & & & \\
\hline \multirow{3}{*}{$\begin{array}{l}\text { Mobil_bağımlılık } \\
\text { çalışılan pozisyon }\end{array}$} & Gruplararas1 & 1,180 & 5 & 0,236 & 1,069 & 0,377 \\
\hline & Gruplariçi & 96,427 & 437 & 0,221 & & \\
\hline & Toplam & 97,607 & 442 & & & \\
\hline \multirow{3}{*}{$\begin{array}{l}\text { Mobil_bağımlılık } \\
\text { kullanım yılı }\end{array}$} & Gruplararası & 1022,491 & 67 & 15,261 & 3,078 & 0,000 \\
\hline & Gruplariçi & 1859,166 & 375 & 4,958 & & \\
\hline & Toplam & 2881,657 & 442 & & & \\
\hline \multirow{3}{*}{$\begin{array}{l}\text { Mobil_bağımlılık } \\
\text { kullanım süresi-günlük }\end{array}$} & Gruplararas1 & 1055,335 & 67 & 15,751 & 1,779 & 0,000 \\
\hline & Gruplariçi & 3319,491 & 375 & 8,852 & & \\
\hline & Toplam & 4374,826 & 442 & & & \\
\hline \multirow{3}{*}{$\begin{array}{l}\text { SG kabullenme_niyeti } \\
\text { yaş }\end{array}$} & Gruplararas1 & 3,169 & 30 & 0,106 & 0,844 & 0,706 \\
\hline & Gruplariçi & 51,584 & 412 & 0,125 & & \\
\hline & Toplam & 54,753 & 442 & & & \\
\hline \multirow{3}{*}{$\begin{array}{l}\text { 5G kabullenme_niyeti } \\
\text { eğitim durumu }\end{array}$} & Gruplararası & 0,812 & 3 & 0,271 & 2,204 & 0,087 \\
\hline & Gruplariçi & 53,941 & 439 & 0,123 & & \\
\hline & Toplam & 54,753 & 442 & & & \\
\hline \multirow{3}{*}{$\begin{array}{l}\text { 5G kabullenme_niyeti } \\
\text { çalışılan alan }\end{array}$} & Gruplararası & 0,928 & 1 & 0,928 & 7,599 & 0,006 \\
\hline & Gruplariçi & 53,826 & 441 & 0,122 & & \\
\hline & Toplam & 54,753 & 442 & & & \\
\hline \multirow{3}{*}{$\begin{array}{l}\text { 5G kabullenme_niyeti } \\
\text { çalışılan pozisyon }\end{array}$} & Gruplararas1 & 2,468 & 5 & 0,494 & 4,125 & 0,001 \\
\hline & Gruplariçi & 52,286 & 437 & 0,120 & & \\
\hline & Toplam & 54,753 & 442 & & & \\
\hline \multirow{3}{*}{$\begin{array}{l}\text { 5G kabullenme_niyeti } \\
\text { kullanım yılı }\end{array}$} & Gruplararası & 448,584 & 43 & 10,432 & 1,711 & 0,005 \\
\hline & Gruplariçi & 2433,073 & 399 & 6,098 & & \\
\hline & Toplam & 2881,657 & 442 & & & \\
\hline \multirow{3}{*}{$\begin{array}{l}\text { 5G kabullenme_niyeti } \\
\text { kullanım süresi-günlük }\end{array}$} & Gruplararası & 1182,749 & 43 & 27,506 & 3,438 & 0,000 \\
\hline & Gruplariçi & 3192,077 & 399 & 8,000 & & \\
\hline & Toplam & 4374,826 & 442 & & & \\
\hline
\end{tabular}


Tablo 3.7. Ortalama değerler (Mean values)

\begin{tabular}{|c|c|c|c|}
\hline & & $\mathbf{N}$ & Ortalama \\
\hline \multirow{2}{*}{$\begin{array}{l}\text { Mobil_bağımlılık } \\
\text { cinsiyet }\end{array}$} & Erkek & 255 & 2,9542 \\
\hline & Kadın & 188 & 3,0741 \\
\hline \multirow{3}{*}{$\begin{array}{l}\text { Mobil_bağımlılık } \\
\text { yaş }\end{array}$} & $20-30$ & 133 & 3,0785 \\
\hline & $31-40$ & 249 & 2,986 \\
\hline & $41-51$ & 61 & 2,6676 \\
\hline \multirow{2}{*}{$\begin{array}{l}\text { Mobil_bağımlılık } \\
\text { çalışılan alan }\end{array}$} & Teknik & 283 & 2,9496 \\
\hline & Ticari & 160 & 3,1031 \\
\hline \multirow{2}{*}{$\begin{array}{l}\text { 5G kabullenme_niyeti } \\
\text { çalışılan alan }\end{array}$} & Teknik & 283 & 3,6451 \\
\hline & Ticari & 160 & 3,7403 \\
\hline \multirow{6}{*}{$\begin{array}{l}\text { 5G kabullenme_niyeti } \\
\text { çalışılan pozisyon }\end{array}$} & Teknik-Ticari-Destek Personeli & 88 & 3,6182 \\
\hline & Uzman Yard.-Mühendis-Uzman-Yetkili-Temsilci & 159 & 3,6588 \\
\hline & Ekip Yöneticileri-Kıdemli Uzmanlar-Proje Yöneticileri-Eksperler & 132 & 3,7091 \\
\hline & Teknik-Ticari-Destek Departman Müdürü-Grup Müdürü-İl/İlçe Müdürü & 61 & 3,7730 \\
\hline & $\begin{array}{l}\text { Direktör-Teknik-Ticari-Destek Bölge Müdür Yardımcısı- Bölge Müdürü- } \\
\text { Genel Müdür }\end{array}$ & 2 & 3,8000 \\
\hline & Diğer & 1 & 2,5000 \\
\hline
\end{tabular}

Mobil bağımlılık durumu bağımsız değişkenlere göre Oneway Anova varyans analizi testi sonuçlarına göre yaş, çalışılan alan, kullanım yılı ve günlük kullanım süresine göre istatistiksel olarak anlamlıdır $(p<0.05)$, eğitim durumu ve çalışılan pozisyona göre istatistiksel olarak anlamsızdır $(\mathrm{p}>0.05)$. Ortalama değerlerine bakıldığında 20-30 yaş arasında bulunanların diğer yaş gruplarına göre, ticari alanda çalışanların teknik alanda çalışanlara göre mobil bağımlılık durumunun daha fazla olduğu görülmektedir. Mobil internet kullanım yılı ve günlük kullanım süresi arttıkça mobil bağımlılık artmaktadır. 5G teknolojisi kabullenme niyeti One-way Anova varyans analizi testi sonuçlarına göre çalışılan alan, pozisyona, mobil internet kullanım yılı ve günlük kullanım süresine göre istatistiksel olarak anlamlıdır $(p<0.05)$, yaş ve eğitim durumuna göre istatistiksel olarak anlamsızdır ( $\mathrm{p}>0.05)$. Ortalama değerlerine bakıldığında $5 \mathrm{G}$ teknolojisi kabullenme niyeti ticari alanda çalışanların teknik alanda çalışanlara göre daha fazla olduğu ve çalışılan pozisyonun yükselmesine göre $5 \mathrm{G}$ teknolojisi kabullenme niyetinin arttığı bulunmaktadır. Mobil internet kullanım yılı ve günlük kullanım süresi arttıkça $5 \mathrm{G}$ teknolojisi kabullenme niyeti de artmaktadir.

\section{Doğrulayıcı Faktör Analizi (DFA)}

Uygulanan anket çalışması ile elde edilen verilerin yapısal geçerliliği DFA ile araştırılmıştır. DFA'da faktörler arası uyuma bakılmıştır. Literatürde yer alan kabul edilebilir uyum değerlerine göre değerlendirme yapılmıştır. Değerlendirmeler uyum iyiliği indeksi GFI (Goodness of Fit Index), karşılaştırmalı uyum indeksi CFI (Comparative Fit Index), yaklaşık hataların ortalama karekökü RMSEA (Root Mean Square Error of Approximation), hata kareler ortalamasının karekökü RMR (Root Mean Square Residuals), normlaştırılmış uyum indeksi NFI (Normed Fit Index) uyum ölçütlerine göre yorumlanmıştır.

Tablo 3.8. DFA uyum değerleri [7,26] (CFA compliance values)

\begin{tabular}{|l|l|l|}
\hline DFA Ölçütleri & $\begin{array}{l}\text { Kabul edilebilir } \\
\text { değer }\end{array}$ & İyi uyum aralığı \\
\hline Ki-kare /Serbestlik & $\mathrm{x}^{2}<\mathrm{df}<5$ & $\mathrm{x}^{2}<\mathrm{df}<3$ \\
\hline
\end{tabular}

\begin{tabular}{|l|l|l|}
\hline CFI & $0,05 \leq \mathrm{CFI} \leq 0,97$ & $0,07 \leq \mathrm{CFI} \leq 1$ \\
\hline RMR & $0,05 \leq \mathrm{RMSEA} \leq 1$ & $0 \leq \mathrm{RMR} \leq 0,05$ \\
\hline GFI & $0,00 \leq \mathrm{GFI} \leq 0,95$ & $0,05 \leq \mathrm{GFI} \leq 1$ \\
\hline NFI & $0,00 \leq \mathrm{NFI} \leq 0,95$ & $0,05 \leq \mathrm{NFI} \leq 1$ \\
\hline RMSEA & $0,05 \leq \mathrm{RMSEA} \leq 1$ & $0 \leq \mathrm{RMSEA} \leq 0,05$ \\
\hline p & $\mathrm{p}<0.05$ & $\mathrm{p}<0.05$ \\
\hline
\end{tabular}

Mobil bağımlılık durumu ve $5 \mathrm{G}$ teknolojisi kabullenme niyetine ait şemalar Şekil 3.3. ve Şekil 3.4.'dedir.

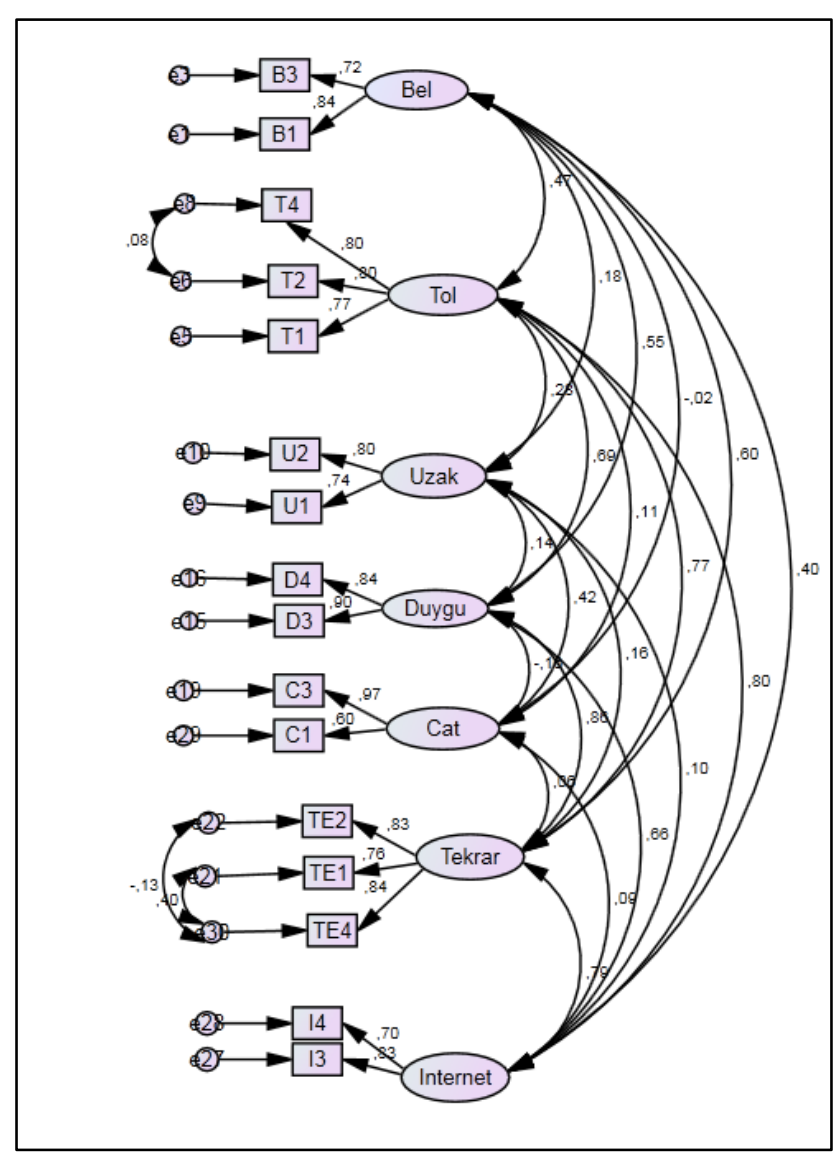

Şekil 3.3. Mobil bağımlılık durumu 1.düzey DFA şeması (Mobile addiction status level 1 CFA scheme) 
Mobil bağımlılık ölçeği modelinde;

Duygusal değişim faktörü D1 ve D2 maddeleri,

Tekrarlama faktörü TE3 maddesi,

Tolerans faktörü T3 maddesi,

Uzaklaşım faktörü U3 ve U4 maddeleri,

Belirginlik faktörü B2 ve B4 maddeleri,

Çatışma faktörü C2 ve C4 maddeleri,

Mobil internet eğilimi I1 ve I2 maddeleri

Uyum ölçütleri $\mathrm{x}<0,7$ olduğu için DFA 1.düzeyde analizden çıkarılmıştır.

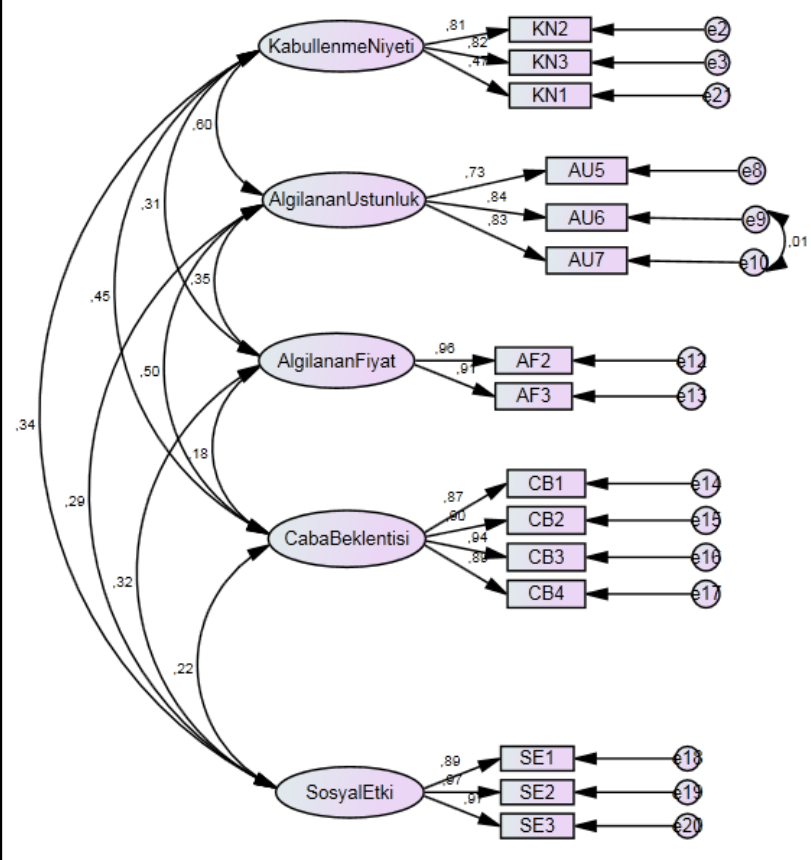

Şekil 3.4. 5G teknolojisi kabullenme niyeti 1.düzey DFA şemas1

(5G technology acceptance intention level 1 CFA scheme)

5G teknolojisi kabullenme niyeti modelinde;

Alg1lanan fiyat faktörü AF1 maddesi,

Algılanan üstünlük faktörü AU1, AU2, AU3 ve AU4 maddeleri uyum ölçütleri $\mathrm{x}<0,7$ olduğu için analizden çıkarılmıştır.

Doğrulayıcı faktör analizi 2. düzey sonucunda mobil bağımlılık durumu ve $5 \mathrm{G}$ teknolojisi kabullenme niyetini gösteren şemalar Şekil 3.5. ve Şekil 3.6.'dadır.

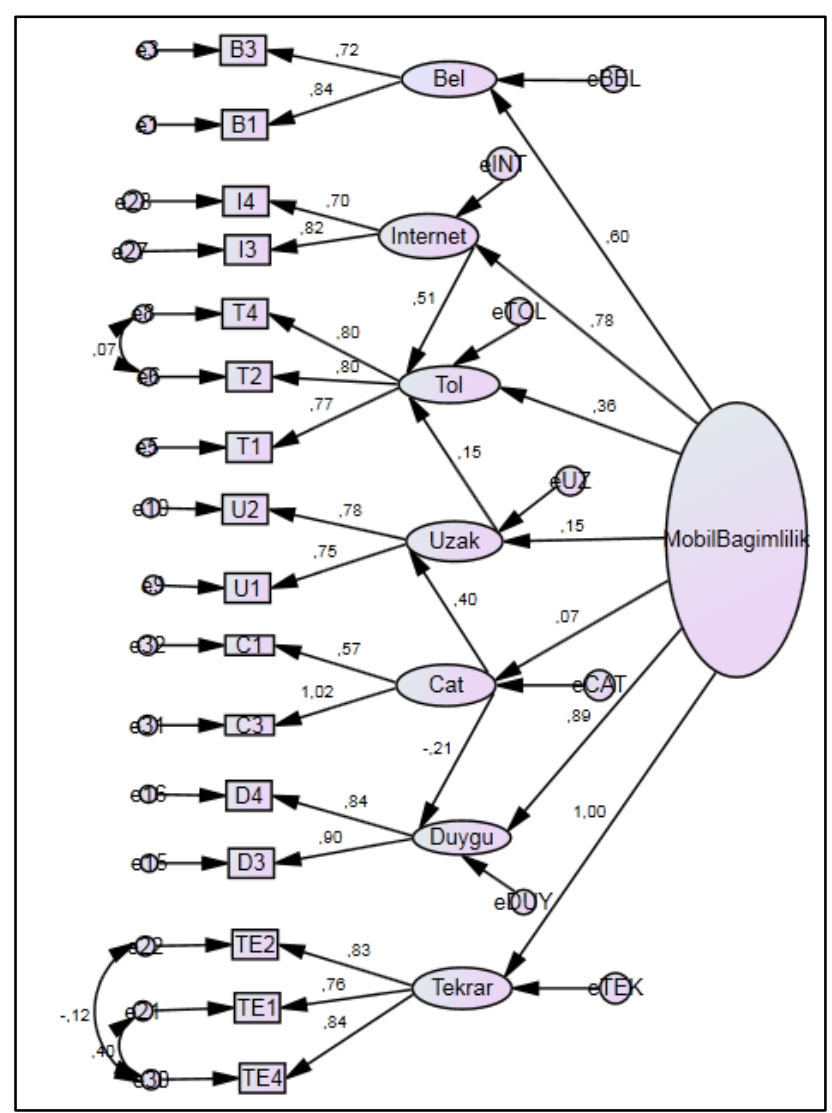

Şekil 3.5. Mobil bağımlılık durumu 2. düzey DFA şeması (Mobile addiction status level 2 CFA scheme)

Mobil bağımlılık durumuna ilişkin en düşük değere sahip değişken çatışma, en yüksek değere sahip değişken tekrarlamadir.

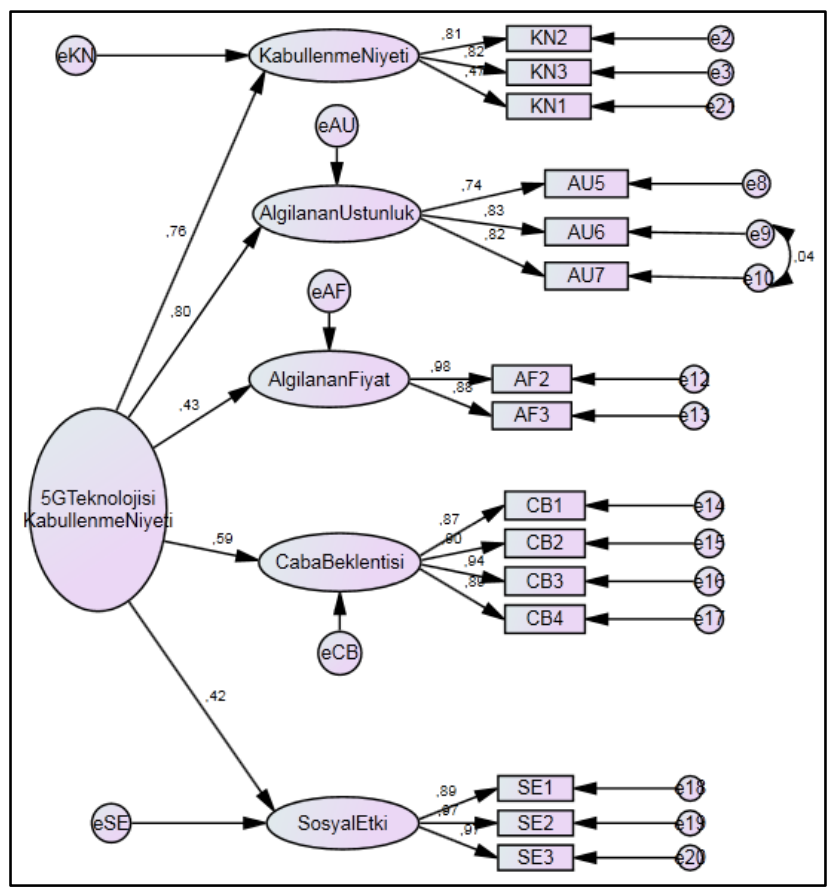

Şekil 3.6. 5G teknolojisi kabullenme niyeti 2.düzey DFA şemas1

(5G technology acceptance intention level 2 CFA scheme) 
5G teknolojisi kabullenme niyetine ilişkin en düşük değere sahip değişken sosyal etki, en yüksek değere sahip değişken algılanan üstünlüktür.

2.düzey DFA sonuçlarına göre mobil bağımlılık durumu ve $5 \mathrm{G}$ teknolojisi kabullenme niyeti uyum değerleri Tablo 3.9'dadır.

Tablo 3.9. DFA uyum durumu

\begin{tabular}{|l|l|l|l|}
\hline $\begin{array}{l}\text { DFA } \\
\text { Ölçütleri }\end{array}$ & $\begin{array}{l}\text { Mobil } \\
\text { bağımlılık }\end{array}$ & $\begin{array}{l}\text { 5G teknolojisi } \\
\text { kabullenme niyeti }\end{array}$ & $\begin{array}{l}\text { Uyum } \\
\text { durumu }\end{array}$ \\
\hline $\begin{array}{l}\text { Ki-kare } \\
\text { Serbestlik }\end{array}$ & 2,685 & 2,683 & Çok iyi \\
\hline CFI & 0,958 & 0,973 & Çok İyi \\
\hline RMR & 0,040 & 0,027 & Çok iyi \\
\hline GFI & 0,934 & 0,936 & Çok iyi \\
\hline NFI & 0,936 & 0,958 & Çok iyi \\
\hline RMSEA & 0,062 & 0,062 & İyi \\
\hline p & 0,000 & 0,000 & İyi \\
\hline
\end{tabular}

Mobil bağımlılık DFA 2.düzey sonuçlarına göre ki-kare değeri 2,685 ile çok iyi uyum aralığındadır. CFI, GFI ve NFI değerlerinin 0,9'un üzerinde olması modelin çok iyi uyum içerisinde olduğunu, RMR değerinin 0,05 'ten düşük olması modelin çok iyi uyum içerisinde olduğunu ve RMSEA değerinin $0,08^{\prime}$ in altında olması modelin iyi uyum içerisinde olduğunu göstermektedir. 5G teknolojisi kabullenme niyeti DFA 2.düzey sonuçlarına göre ki-kare değeri 2,683 iyi uyum aralığındadır. CFI, GFI ve NFI değerlerinin 0,9 'un üzerinde olması modelin çok iyi uyum içerisinde olduğunu, RMR değerinin 0,05 'ten düşük olması modelin çok iyi uyum içerisinde olduğunu ve RMSEA değerinin 0,08 'in altında olması yine modelin iyi uyum içerisinde olduğunu göstermektedir.

Mobil bağımlılık ölçeğinde, $\mathrm{CFI}=0,958, \quad \mathrm{GFI}=0,934$, $\mathrm{NFI}=0,936, \mathrm{RMR}=0,040, \mathrm{RMSEA}=0,062$ ve $\mathrm{x}^{2} / \mathrm{df}=2,685$, $\mathrm{p}<0,05$ olup iyi uyum göstermektedir.

$5 \mathrm{G}$ teknolojisi kabullenme niyeti ölçeğinde, $\mathrm{CFI}=0,973$, $\mathrm{GFI}=0,936, \mathrm{NFI}=0,958, \mathrm{RMR}=0,027, \mathrm{RMSEA}=0,062$ ve $\mathrm{x}^{2} / \mathrm{df}=2,683, \mathrm{p}<0,05$ olup iyi uyum göstermektedir.

\section{Regresyon analizi}

Yapısal geçerliliği belirlenen iki değişken 5G teknolojisi kabullenme niyeti ve mobil bağımlılık durumu arasındaki ilişkiyi incelemek amacıyla regresyon analizi yapılmıştır. 5G teknolojisi kabullenme niyeti bağımlı değişkeni ile mobil bağımlılık bağımsız değişkeni arasındaki ilişkinin matematiksel olarak ifadesi belirlenmiştir. Araştırma sonucu Tablo 3.10'dadir.

Tablo 3.10. 5G teknolojisi kabullenme niyeti ve mobil bağımlılık regresyon analizi (5G technology acceptance intention and mobile addiction regression analysis)

\begin{tabular}{|c|c|c|c|c|c|c|}
\hline \multicolumn{7}{|c|}{ Modelin Özeti } \\
\hline Model & $\mathrm{R}$ & $\mathrm{R}^{2}$ & Düzeltilmiş $\mathrm{R}^{2}$ & \multicolumn{3}{|c|}{ Tahminin standart hatası } \\
\hline 1 & 0,41 & 0,168 & 0,166 & \multicolumn{3}{|c|}{0,38049} \\
\hline \multicolumn{7}{|c|}{ Katsayılar } \\
\hline \multirow[t]{2}{*}{ Model } & & $\begin{array}{l}\text { Standartlanmamış } \\
\text { Katsayılar }\end{array}$ & & Standart Katsayılar & $\mathrm{t}$ & $\mathrm{p}$ \\
\hline & & $\mathrm{B}$ & Std. Hata & Beta & & \\
\hline \multirow[t]{2}{*}{1} & (Sabit) & 2,757 & 0,117 & & 23,54 & 0 \\
\hline & Mobil_bağımlılık & 0,363 & 0,039 & 0,41 & 9,427 & 0 \\
\hline
\end{tabular}

5G teknolojisi kabullenme niyeti ve mobil bağımlılık durumu arasındaki regresyon analizi sonucuna göre mobil bağımlılık ve $5 \mathrm{G}$ teknolojisi kabullenme niyeti arasında pozitif yönde ilişki bulunmaktadır $(\mathrm{p}<0.05)$. Mobil bağımlılık durumu yüksek olanlar $5 \mathrm{G}$ teknolojisini daha kolay benimsemektedir. 5G teknolojisi kabullenme niyeti ile mobil bağımlılık arasındaki ilişki matematiel olarak aşağıdaki şekilde ifade edilebilir.

\section{$5 G$ Teknolojisi Kabullenme Niyeti $=2,757+0,363 *$ Mobil Bağımlılık}

\section{SONUÇ, TARTIŞMA VE ÖNERILER (RESULT, DISCUSSION AND RECOMMENDATIONS)}

$\mathrm{Bu}$ çalışma ile mobil kullanıcıların 5G teknolojisi kabullenme niyetlerine mobil bağımlılık durumunun etkisi incelenmiştir. Mobil bağımlılık durumu ve 5G teknolojisi kabullenme niyeti ölçeklerle araştırılmış, ölçme araçlarının güvenilirliği DFA ile test edilmiştir.
Mobil bağımlılı̆̆ın kadınlarda, 20-30 yaş arası gençlerde, ticari alanlarda çalışanlarda daha fazla olduğu görülmüştür. 5G teknolojisi kabullenme niyetinde ise ticari alanda çalışanlar ve çalışılan pozisyonun artmasıyla daha da arttığı görülmüştür. Geçmişten günümüze mobil telefon ve teknolojilerin kullanım yılı arttıkça mobil bağımlılık ve $5 \mathrm{G}$ teknolojisi kabullenme niyeti artmaktadır. Yine aynı şekilde günlük kullanım süresinin artması mobil bağımlılı̆̆1 artırdığı gibi yeni teknoloji olan 5G'yi kabullenme niyetini de artırmaktadır.

Mobil bağımlılığı etkileyen en yüksek faktörün tekrarlama olduğu, en düşük faktörün çatışma olduğu araştırmada belirlenmiştir. Fidan'ın [7] yaptığı çalışma ile toleransın birinci sırada, mobil internet eğiliminin ikinci sırada, tekrarlamanın üçüncü sırada mobil bağımlılığı en çok etkileyen faktör olduğu ve en düşük etkiye sahip olan faktörün çatışma olduğu görülmektedir. Bu durumda iki çalışma arasında mobil bağımlılığı en çok etkileyen faktörde farklılık, en az etkileyen faktörde paralellik bulunmaktadır. Bu çalışma ve Fidan'ın [7] çalışması faktör uyumu sonrası çıkarılan maddeler arasında da uyum 
görülmektedir. Her iki çalışmada da Tekrarlama (TE3 kişinin mobil telefon kullanımını bırakması için çaba göstermesi), Uzaklaşım (U3 kişinin mobil telefonunun yanında olmaması durumunda onunla yapacağı işleri düşündüğü, U4 kişinin mobil telefonunun bilek ve boyun ağrilarının sebebi olarak gördüğü) ve Belirginlik (B4 mobil telefonun kişiye her şeyden daha cazip geldiği) maddeleri çıkarılmıştır. Duygusal değişim Fidan'ın [7] çalışmasında uyum ölçütleri kabul edilebilir seviyenin altında çıktığ dahil edilmemesine rağmen bu çalışmada uyumu iyi bulunmuş ve dahil edilmiştir, sadece D1 (sıkıntı anında mobil telefon ile ilgilenmenin kişiyi rahatlatacağı) ve D2 (mobil telefon kullandığı esnada kişinin ansızın "Ben ne yapıyorum" diye bırakması) maddeleri çıkarılmıştır. Kwon vd. [22] uzaklaşım için belirlediği U3 (kişinin mobil telefonu yanında olmadığı zaman onunla yapacağı işleri düşünmesi) ve U4 (kişinin mobil telefonunun bilek ve boyun ağrılarının sebebi olarak gördüğü) maddeleri bu çalışmadan çıkarılmıştır, diğer maddeler ile uyumludur. Kuss vd. [21] tekrarlama için belirlediği TE3 (kişinin mobil telefon kullanımını bırakması için çaba göstermesi) maddesi bu çalışmada çıkarılmış olup diğer maddeler ile uyumludur.

5G teknolojisi kabullenme niyetini etkileyen en yüksek faktörün algılanan üstünlük olduğu, en düşük faktörün sosyal etki olduğu bu çalışmada belirlenmiştir. Xu vd. [33] Hong Kong'da yaşayan 2G teknolojisini bırakıp 3G teknolojisini yeniden kullanmaya başlayanların $3 \mathrm{G}$ teknolojisi kabullenme niyetini en çok etkileyen faktörü çaba beklentisi olarak belirlemiştir. Telekomünikasyon şirketi çalışanları ile Hong Kong Kong'da yaşayan 2G teknolojisini bırakıp 3G teknolojisini yeniden kullanmaya başlayanların 5G'yi kabullenme niyetlerini en çok etkileyen faktör farklılık göstermektedir. 5G teknolojisi kabullenme niyetini en az etkileyen faktör Xu vd. [33] çalışmasında algılanan üstünlük iken, bu çalışmada sosyal etkidir. Bu çalışmada ise, algılanan üstünlükte yer alan yedi maddenin dördü AU1 (5G mevcut mobil teknolojilere göre küçük bir ilerleme gösteriyor), AU2 (5G mobil teknolojilerde köklü değişime dayanıyor), AU3 (5G mevcut mobil teknolojilere göre önemli bir yeniliktir) ve AU4 (5G'nin diğer teknolojilerin yerini alması zor olan uygulamalara yol açar) uyumu olumsuz etkilediği için analizden çıkarılmıştır. Bu seviyede kısmen tutarlılık bulunmaktadır.

Genel olarak değerlendirilen sonuçlara göre bu çalışmada değerlendirilen mobil bağımlılık durumu ve $5 \mathrm{G}$ teknolojisini kabullenme niyeti literatürdeki diğer çalışmalarla kısmen tutarlılık göstermektedir.

Çalışmanın ana amacı 5G teknolojisini kabullenme niyetine mobil bağımlılık durumunun etkisini incelemektir. Araştırmada 5G teknolojisini kabullenme niyeti ve mobil bağımlılık arasında pozitif yönde anlamlı ilişki bulunduğu gözlemlenmiş olup $(\mathrm{r}=0,41)$, mobil bağımlılığ 1 yüksek olan kişilerin $5 \mathrm{G}$ teknolojisini daha kolay kabullendiği söylenebilir.

Bu çalışmanın 5G teknolojisi ve mobil bağımlılıkla ilgili çalışmalarda diğer araştırmacılara katkı sağlaması beklenmektedir. Mobil bağımlılığı en çok etkileyen bağımlılığın bir süre ara verilse bile tekrar başlaması olan tekrarlama faktörü, var olan hizmetlerin iyileştirilmesi ve yeni hizmetlerin geliştirilmesinde, kullanıcıların psikolojik durumunda göz önünde bulundurulmalıdır. Yeni bir teknoloji olan $5 \mathrm{G}$ teknolojisi kabullenme niyetine etki eden faktörlerin, yatırımların doğru planlanması, kullanıcıların teknoloji hakkındaki farkındalığının oluşturulması gibi çalışmalarda literatüre katkı sağlaması beklenmektedir.

$\mathrm{Bu}$ çalışma uygulandığg örneklem ile sınırlıdır. $\mathrm{Bu}$ teknolojiyi kullanan diğer paydaşları içeren örneklemlerle ilgili daha çok çalışma yapılmalıdır. Mobil bağımlılığg hem kendi içinde hem de birbiriyle olan ilişkisini anlamada yeni araştırmacılara önerilebilir. $\mathrm{Bu}$ çalışmada 5G teknolojisi kabullenme niyeti için kullanılan parametrelerin daha gelişmiş̧ olan çalışmalardaki parametreler kullanılarak incelenmesi de yeni araştırmacılara önerilebilir.

\section{KAYNAKLAR (REFERENCES)}

[1] I. F. Akyildiz, S. Nie, S. C. Lin, M. Chandrasekaran, "5G Roadmap: 10 Key Enabling Technologies", Elsevier, 106, 17-48, 2016.

[2] A. Baltacı, "Nitel Araştırmalarda Örnekleme Yöntemleri ve Örnek Hacmi Sorunsalı Üzerine Kavramsal Bir İnceleme”, Bülent Ecevit Üniversitesi Sosyal Bilimler Enstitüsü Dergisi, 7(1), 231-274, 2018.

[3] M. Choliz, "Mobile-phone addiction in adolescence: The test of mobile phone dependence (TMD)", Progress in Health Sciences, 2(1), 33-44, 2012.

[4] H. E. Çelik, V. Yılmaz, V. Pazarlıŏglu "Teknoloji Kabul Modeli ve Bir Uygulama”, Finans Politik \& Ekonomik Yorumlar, 47(540), 35-43, 2010.

[5] K. Demirci, H. Orhan, A. Demirdaş, A. Akpınar, H. Sert, "Validity and reliability of the Turkish version of the smartphone addiction scale in a younger population", Klinik Psikofarmakoloji Bülteni, 24(3), 226-34, 2014.

[6] H. Erdem, U. Türen, G. Kalkın, "Mobil telefon yoksunluğu korkusu (Nomofobi) yayılımı: Türkiye'deki üniversite öğrencileri ve kamu çalışanları örneklemi”, Bilişim Teknolojileri Dergisi, 10(1), 1-12, 2017.

[7] H. Fidan, "Mobil Bağımlılık Ölçeği'nin geliştirilmesi ve geçerliliği: Bileşenler Modeli Yaklaşımı", Addicta: The Turkish Journal on Addictions, 3, 433-469, 2016.

[8] M. D. Griffiths, “Technological addictions”, Clinical Psychology Forum, 76, 14-19, 1995.

[9] İnternet: T. Anjarwalla, Inventor of cell phone: We knew someday everybody would have one, http://edition.cnn.com/2010/TECH/mobile/07/09/cooper.cell.phon e.inventor/, 03.12.2018.

[10] İnternet: Bilgi Teknolojileri Kurumu (BTK), 20183 Aylık Pazar Verileri Raporu, https://www.btk.gov.tr/uploads/pages/pazarverileri/2018-2ceyrekraporu.pdf, 20.12.2018. 
[11] İnternet: Bilgi Teknolojiler Kurumu (BTK), 5G ve Dikey Sektörler Raporu, https://www.btk.gov.tr/uploads/announcements/5g-vedikey-sektorler-raporu-yayimlandi/201803085gvedikeysektorlerraporu.pdf, 10.12.2018.

[12] İnternet: Ericson, Mobility https://www.ericsson.com/assets/local/mobilityreport/documents/2018/ericsson-mobility-report-june-2018.pdf, 23.12.2018.

[13] İnternet: GSMA, GSMA Intelligence, The Mobile Economy https://www.gsma.com/mobileeconomy/wpcontent/uploads/2018/05/The-Mobile-Economy-2018.pdf, 23.12.2018.

[14] İnternet: ITU, ITU IMT-2020 (5G) Hedef Belgesi, https://www.itu.int/en/ITU-R/study-groups/rsg5/rwp5d/imt2020/Documents/S01-1_Requirements\%20for\%20IMT2020_Rev.pdf, 10.12.2018.

[15] İnternet: Misone, Türkiye'nin 5G Vizyonu, http://www.misonesolution.com/uploads/1/0/5/9/10590997/5g_yo lharitasi_misone.pdf, 20.12.2018.

[16] İnternet: Ovum, 5G Service Provider Tracker 2Q18, https://ovum.informa.com/resources/product-content/5g-serviceprovider-tracker-2q18, 10.12 .2018 .

[17] İnternet: Türkiye İstatistik Kurumu (TÜIK), Hanehalkı Bilişim Teknolojileri (BT) Kullanım Araştırması, http://www.tuik.gov.tr/PreHaberBultenleri.do?id=27819, 13.12.2018.

[18] İnternet: Türkiye İstatistik Kurumu (TÜIK), Temel Nüfus Verileri, http://www.tuik.gov.tr/UstMenu.do?metod=temelist, 13.12.2018.

[19] İnternet: Türk Telekom, 5G Kitabı, https://www.turktelekom.com.tr/hakkimizda/duyurular/Document s/tt-5g-final-version-03082018.pdf, 10.11.2018.

[20] D. Kim, Y. Lee, J. Lee, J. K. Nam, Y. Chung, "Development of Korean Smartphone Addiction Proneness Scale for Youth", PLoS ONE, 9(5), 1-7, 2014.

[21] D. J. Kuss, G. W. Shorter, A. J. Rooij, M. D.Griffiths, T. M. Schoenmakers, "Assessing internet addiction using the parsimonious internet addiction components model a preliminary study", International Journal of Mental Health and Addiction, 12(3), 351-366, 2013.

[22] M. Kwon, J. Y. Lee, W: Y. Won, J. W. Park, J. A. Min, C. Hahn, "Development and validation of a smartphone addiction scale (SAS)", PLoS One, 8(2), 1-7, 2013.

[23] Y. K. Lee, C. T. Chang, Y. Lin, Z. H. Cheng, "The dark side of smartphone usage: Psychological traits, compulsive behavior and technostress", Computers in Human Behavior, 31, 373-383, 2013.
[24] G. Miller, "The smartphone psychology manifesto", Perspectives on Psychological Science, 7(3), 221-237, 2012.

[25] C. O. Noyan, A. E. Darçıı, S. Nurmedov, O. Yılmaz, N. Dilbaz, "Akıllı Telefon Bağımlılı̆̆ Ölçeğinin Kısa Formunun üniversite öğrencilerinde Türkçe geçerlilik ve güvenilirlik çalışması", Anadolu Psikiyatri Dergisi, 16(Özel sayl 1), 73-81, 2015.

[26] N. Özabacı, "İlişki Niteliği Ölçeği'nin Türkçe Uyarlaması: Geçerlik ve Güvenirlik Çalışması", Education and Science. 36(162), 159-167, 2011.

[27] K. Özdamar, Paket Programlar ile İstatistiksel Veri Analizi Çok Değişkenli Analizler, (2), 246-247, Kaan kitapevi, Eskişehir, 1999.

[28] G.R. Patil, P. S. Wankhade, "5G Wireless Technology", International Journal of Computer Science and Mobile Computing, 3(10), 203-207, 2014.

[29] R. S. Sapakal, S. S. Kadam, "5G Mobile Technology" International Journal of Advanced Research in Computer Engineering and Technology, 2(2), 568-571, 2013.

[30] M. Serçemeli, E. Kurnaz, "Denetimde Bilgi Teknoloji Ürünleri Kullanımının Teknoloji Kabul Modeli (TKM) İle Araştırılması", İstanbul Üniversitesi İşletme Fakültesi Dergisi, 45(1), 43-52, 2016.

[31] O. Turel, A. Serenko, P. Giles, "Integrating technology addiction and use: An empirical investigation of online auction users", MIS Quarterly, 35(4), 1043-1061, 2011.

[32] N. G. Uğur, A. H. Turan, "Mobil uygulama kabul modeli: bir ölçek geliştirme çalı̧̧ması", Hacettepe Üniversitesi İktisadi ve İdari Bilimler Fakültesi Dergisi, 34(4), 97-126, 2016.

[33] X. Xu, J. Y. L. Thong, K. Y. Tam, “Winning Back Technology Disadopters: Testing a Technology Readoption Model in the Context of Mobile Internet Services", Journal of Management Information Systems, 34(1), 102-140, 2017.

[34] M. M. Yaşlıoğlu, "Sosyal Bilimlerde Faktör Analizi ve Geçerlilik: Keşfedici ve Doğrulayıcı Faktör Analizlerinin Kullanılması", İstanbul Üniversitesi İşletme Fakültesi Dergisi, 46(özel say1), 74 85, 2012.

[35] K. S. Young, "Internet addiction: The emergence of a new clinical disorder”, CyberPsychology and Behavior, 1(3), 237-244, 1998.

[36] M. Berk, A. Özsoy, İ. Ay, "Mobil Cihazlar Üzerinde Enerji Verimli Sanal Sabit Numara Sistemi”, Bilişsim Teknolojileri Dergisi, 13(1), 77-86, 2020.

[37] İ. Tarımer, S. Şenli, E. Doğan, "Mobil İletişim Cihazları İle Öğrenim Materyallerine Erişim Sağlayan Bir Yazılım Tasarımı", Bilișim Teknolojileri Dergisi, 3(3), 1-6, 2011. 
EK-1. Ankette kullanılan ölçeklerin faktör, soru ve referansları [7]; [33]

\begin{tabular}{|c|c|c|c|}
\hline \multicolumn{2}{|l|}{ Faktörler } & Mobil Bağımlılık Ölçeği Maddeleri & Referans \\
\hline \multirow[t]{4}{*}{ Belirginlik } & B1 & Mobil telefon kullanırken planladığım işleri unuturum. & {$[22]$} \\
\hline & B2 & Mobil telefon kullanmamı engelleyen işler bana sıkıcı gelir. & [21] \\
\hline & B3 & Mobil telefon kullanmazken, telefonda daha önce yaptığım işlemleri düşünürüm. & {$[22]$} \\
\hline & B4 & Mobil telefon kullanmam bana her şeyden daha cazip gelir. & [8] \\
\hline \multirow[t]{3}{*}{ Tolerans } & $\mathrm{T} 1$ & Zaman geçtikçe mobil telefonumu daha sık kontrol etme gereği hissediyorum. & [8] \\
\hline & $\mathrm{T} 2$ & Mobil telefonumu planladığımdan daha uzun süre kullanırım. & [35] \\
\hline & $\mathrm{T} 3$ & Mobil telefonu kullandıktan hemen sonra tekrar kontrol etme gereği hissederim. & [3] \\
\hline \multirow[t]{4}{*}{ Uzaklaşım } & U1 & Mobil telefonum olmadan hayat boş gelir. & {$[22]$} \\
\hline & $\mathrm{U} 2$ & Mobil telefon kullanamadığımda huysuz ve sinirli hissederim. & [21] \\
\hline & $\mathrm{U} 3$ & Mobil telefonum yanımda olmadığında onunla yapacağım işlemleri düşünürüm. & {$[22]$} \\
\hline & U4 & Bilek ve boyun ağrılarımın sebebi olarak mobil telefonumu görüyorum. & {$[22]$} \\
\hline \multirow{4}{*}{$\begin{array}{l}\text { Duygusal } \\
\text { Değişim }\end{array}$} & D1 & Sıkıntılı anlarımda mobil telefonumla ilgilenmek beni rahatlatır. & [21] \\
\hline & D2 & Mobil telefon kullanırken aniden "Ben ne yapıyorum" diyerek bırakırım. & [7] \\
\hline & D3 & Mobil telefonum beni sorunlardan ve olumsuz düşüncelerden uzaklaştırır. & [35] \\
\hline & D4 & Mobil telefon kullanırken kendimi güvende hissederim. & {$[22]$} \\
\hline \multirow[t]{4}{*}{ Çatışma } & $\mathrm{C} 1$ & Mobil telefonumu arkadaş ortamında kullanmam sorun çıkartır. & [21] \\
\hline & $\mathrm{C} 2$ & Mobil telefonumu aşırı kullanıp kullanmadığımla ilgili çelişkiler yaşarım. & [7] \\
\hline & $\mathrm{C} 3$ & Mobil telefonu aşırı kullanmam çevremdekilerle sorun yaşamama neden olur. & [3] \\
\hline & $\mathrm{C} 4$ & Mobil telefon kullanırken çevremdekilerden rahatsız olurum. & {$[22]$} \\
\hline \multirow{4}{*}{ Tekrarlama } & TE1 & Mobil telefon kullanımımı azaltıyorum ama tekrar artıyor. & [8] \\
\hline & TE2 & Mobil telefonla işim bitse dahi kendimi "Biraz daha bakayım" derken buluyorum. & [7] \\
\hline & TE3 & Mobil telefon kullanımını bırakmak için çabalıyorum. & [21] \\
\hline & TE4 & Uzun süre mobil telefon kullanmasam dahi, tekrar başladığımda aşırı kullanımım devam eder. & [8] \\
\hline \multirow{4}{*}{$\begin{array}{l}\text { Mobil } \\
\text { İnternet } \\
\text { Eğgilimi }\end{array}$} & I1 & İnternet kullanmam gereken işlemlerimi mobil telefonumla gerçekleştiririm. & [7] \\
\hline & $\mathrm{I} 2$ & İnternete giremesem mobil telefonun anlamının olmadığını düşünüyorum. & [7] \\
\hline & I3 & İnternet, mobil telefon kullandığım süreyi arttırıyor. & [7] \\
\hline & I4 & Mobil telefonumu elime aldığımda hemen internet bağlantısını kontrol ederim. & [7] \\
\hline Faktörler & & 5G Teknolojisi Kabullenme Niyeti Ölçeği Maddeleri & Referans \\
\hline \multirow{3}{*}{$\begin{array}{l}\text { Kabullenme } \\
\text { Niyeti }\end{array}$} & KN1 & Gelecekte mobil internet servislerini kullanmaya devam etmek niyetindeyim. & [33] \\
\hline & KN2 & 5G tanıtıldığında mobil internet servislerini kullanarak yeniden başlatmayı planlıyorum. & [33] \\
\hline & KN3 & Tanıtıldığı zaman 5G mobil internet servislerini kullanır mısınız? & [33] \\
\hline \multirow{7}{*}{$\begin{array}{l}\text { Alg1lanan } \\
\text { Üstünlük }\end{array}$} & AU1 & 5G mevcut mobil teknolojilere göre küçük bir ilerleme gösteriyor. & [33] \\
\hline & AU2 & 5G mobil teknolojilerde köklü değişime dayanıyor. & [33] \\
\hline & AU3 & 5G mevcut mobil teknolojilere göre önemli bir yeniliktir. & [33] \\
\hline & AU4 & 5G'nin diğer teknolojilerin yerini alması zor olan uygulamalara yol açar. & [33] \\
\hline & AU5 & 5G daha çeşitlendirilmiş servisler getirecektir. & [33] \\
\hline & AU6 & 5G servisleri daha yüksek kalitede olacaktır. & [33] \\
\hline & AU7 & 5G tabanlı servisler daha yüksek değerde olacaktır. & [33] \\
\hline \multirow{2}{*}{$\begin{array}{l}\text { Algilanan } \\
\text { Fiyat Değeri }\end{array}$} & AF1 & 5G mobil internet servisleri makul fiyatlı olacaktır. & [33] \\
\hline & AF2 & 5G mobil internet servisleri verdiğin paraya değecektir. & [33] \\
\hline \multirow{4}{*}{$\begin{array}{l}\text { Çaba } \\
\text { Beklentisi }\end{array}$} & CB1 & 5G mobil internet servislerini kullanmayı öğrenmek benim için kolay olacaktır. & [33] \\
\hline & CB2 & 5G mobil internet servisleriyle etkileşimim açık ve anlaşılabilir olacaktır. & [33] \\
\hline & CB3 & 5G mobil internet servislerinin kullanımını kolay bulacağım. & [33] \\
\hline & CB4 & 5G mobil internet servislerinin kullanımında uzmanlaşmak kolay olacaktır. & [33] \\
\hline \multirow[t]{3}{*}{ Sosyal Etki } & SE1 & Benim için önemli olan insanlar 5G mobil internet servislerini kullanmam gerektiğini düşünüyor. & [33] \\
\hline & SE2 & Davranışımı etkileyen kişiler, 5G mobil İnternet servislerini kullanmam gerektiğini düşünüyor. & [33] \\
\hline & SE3 & Düşüncesine değer verdiğim kişiler, 5G mobil İnternet servislerini tercih etmem gerektiğini düşünüyor. & [33] \\
\hline
\end{tabular}


EK-2. Mobil bağımlılık durumu ve 5G teknolojisi kabullenme niyeti anketi
1 - YaşınıZ
Lütfen tam sayı giriniz

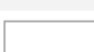

\section{2 - Çalıştığınız il}

Lütfen metin giriniz

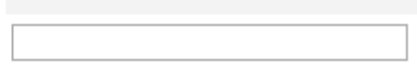

3 - Çalıştığınız ilçe

Lütfen metin giriniz

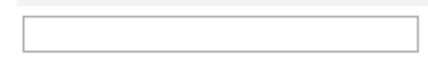

4 - Cinsiyet

Erkek

Kadın

5 - Medeni durum

Evli

Bekar
6 - Eğitim durumu
$\bigcirc$ Ortaöğretim (Lise ve dengi)
Ön lisans
Lisans
Lisansüstü

7 - Çalıştığınız alan

Teknik fonksiyonlar

Ticari ve destek fonksiyonları

8 - Çalıştığınız pozisyon
Teknik-Ticari-Destek personeli
Uzman yard.-Mühendis-Uzman-Yetkili-Temsilci
Ekip yöneticileri-Kıdemli uzmanlar-Proje yöneticileri-Eksperler
Teknik-Ticari-Destek departman müdürü-Grup müdürü-İl/İlçe müdürü
Direktör-Teknik-Ticari-Destek bölge müdür yardımcısı- Bölge müdürü-Danışman-Genel müdür yardımcısı-Genel müdür
Diğer

9 - Kullanılan telefon işletim sistemi
iOs
Android
Windows 


\section{0 - Mevcutta kullanılan teknoloji}

$2 G$

$3 G$

$4 G, 4.5 G(L T E)$

11 - Mobil telefon ile günde geçirilen ortalama süre (saat)

Lütfen tam sayı giriniz

\section{2 - Mobil internet kullanım süresi (yıl)}

Lütfen tam sayı giriniz

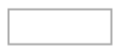

13 - Aşağıda yer alan mobil internet servislerini günlük kullanım sıklığınızı belirtiniz.

Asla

$\bigcirc$

SMS

MMS

Zil sesi ve logo yüklemeler

Mobil oyunlar

Web sitelerini taramak

Mobil e-posta

Mobil uygulamalar

(

O
Nadiren
○

O

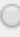

$\bigcirc$

O

$\bigcirc$ 


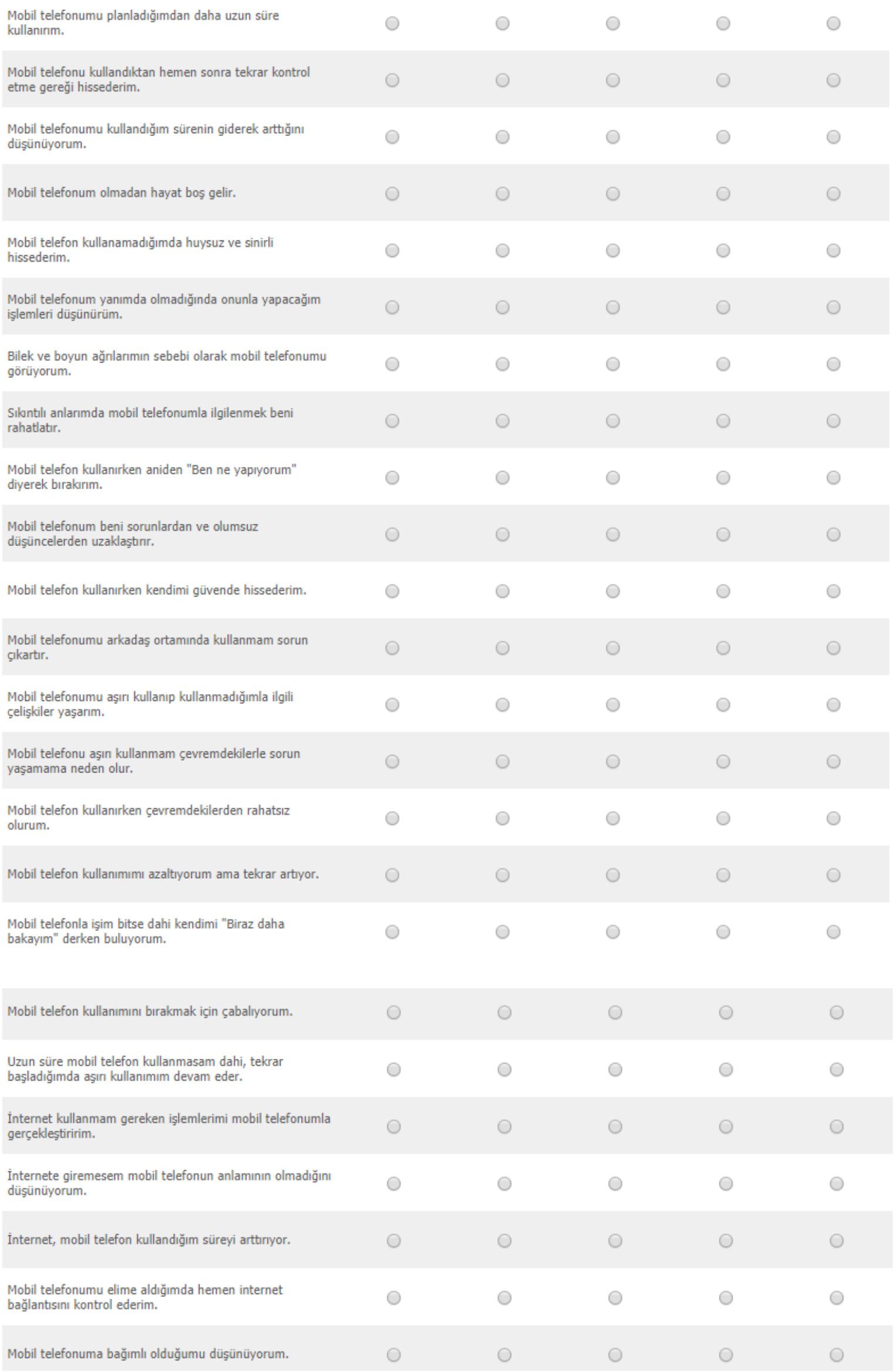


15 - 5 G Teknolojisi Kabullenme Niyeti

Bu bölümde mobil telefon kullanıcılarının mevcut 2G, 3G, 4G-4.5G(LTE) teknolojilerinden sonra cıkacak olan 5G teknolojisini kabullenme niyeti araştırılmaktadır. Lütfen maddelere katılım durumunuzu belirten en uygun seçeneği işaretleyiniz.

\begin{tabular}{|c|c|c|c|c|c|}
\hline & $\begin{array}{c}\text { Tamamen } \\
\text { Katiliyorum }\end{array}$ & Katılıyorum & Kararsızım & Katılmıyorum & $\begin{array}{c}\text { Kesinlikle } \\
\text { katılmıyorum }\end{array}$ \\
\hline $\begin{array}{l}\text { Gelecekte mobil internet servislerini kullanmaya devam etmek } \\
\text { niyetindeyim. }\end{array}$ & 0 & 0 & 0 & O & 0 \\
\hline $\begin{array}{l}\text { 5G tanitıldığında mobil internet servislerini kullanarak yeniden } \\
\text { başlatmayı planlıyorum. }\end{array}$ & 0 & O & 0 & 0 & $\bigcirc$ \\
\hline Tanitıldığı zaman $5 \mathrm{G}$ mobil internet servislerini kullanır mısınız? & $\bigcirc$ & $\bigcirc$ & $\bigcirc$ & $\bigcirc$ & O \\
\hline $\begin{array}{l}\text { 5G, mevcut( } 2 \mathrm{G}, 3 \mathrm{G}, 4 \mathrm{G}-4.5 \mathrm{G}(\mathrm{LTE})) \text { mobil teknolojilere göre küçük bir } \\
\text { ilerleme gösteriyor. }\end{array}$ & $\bigcirc$ & O & $\bigcirc$ & $\bigcirc$ & $\bigcirc$ \\
\hline 5G mobil teknolojilerde köklü değiş̧ime dayanıyor. & 0 & O & O & 0 & O \\
\hline $\begin{array}{l}5 \mathrm{G} \text {, mevcut( } 2 \mathrm{G}, 3 \mathrm{G}, 4 \mathrm{G}-4.5 \mathrm{G}(\mathrm{LTE})) \text { mobil teknolojilere göre önemli } \\
\text { bir yeniliktir. }\end{array}$ & $\bigcirc$ & O & $\bigcirc$ & 0 & $\bigcirc$ \\
\hline $\begin{array}{l}5 \mathrm{G} \text { 'nin diğer( } 2 \mathrm{G}, 3 \mathrm{G}, 4 \mathrm{G}-4.5 \mathrm{G}(\mathrm{LTE})) \text { teknolojilerin yerini alması zor } \\
\text { olan uygulamalara yol açar. }\end{array}$ & $\bigcirc$ & O & O & $\bigcirc$ & $\bigcirc$ \\
\hline $\begin{array}{l}5 \mathrm{G} \text {, mevcut(2G, 3G, 4G-4.5G(LTE)) mobil teknolojilere göre daha } \\
\text { çşitlendirilmiş servisler getirecektir. }\end{array}$ & $\bigcirc$ & O & $\bigcirc$ & $\bigcirc$ & $\bigcirc$ \\
\hline $\begin{array}{l}\text { 5G servisleri, mevcut( } 2 \mathrm{G}, 3 \mathrm{G}, 4 \mathrm{G}-4.5 \mathrm{G}(\mathrm{LTE})) \text { mobil servislere göre } \\
\text { daha yüksek kalitede olacaktır. }\end{array}$ & $\bigcirc$ & O & O & $\bigcirc$ & 0 \\
\hline $\begin{array}{l}5 \mathrm{G} \text { tabanlı servisler, mevcut( } 2 \mathrm{G}, 3 \mathrm{G}, 4 \mathrm{G}-4.5 \mathrm{G}(\mathrm{LTE})) \text { mobil servislere } \\
\text { göre daha yüksek değerde olacaktır. }\end{array}$ & O & O & $\bigcirc$ & $\bigcirc$ & $\bigcirc$ \\
\hline $\begin{array}{l}5 \mathrm{G} \text { mobil internet servisleri, mevcut( } 2 \mathrm{G}, 3 \mathrm{G}, 4 \mathrm{G}-4.5 \mathrm{G}(\mathrm{LTE})) \text { mobil } \\
\text { servislere göre makul fiyatı olacaktır. }\end{array}$ & 0 & O & O & $\bigcirc$ & $\bigcirc$ \\
\hline $5 \mathrm{G}$ mobil internet servisleri verdiğin paraya değecektir. & $\bigcirc$ & 0 & $\bigcirc$ & $\bigcirc$ & 0 \\
\hline 5G mobil internet servisleri mevcut fiyata göre iyi değer sağlayacaktur. & 0 & 0 & $\bigcirc$ & 0 & 0 \\
\hline $\begin{array}{l}5 \mathrm{G} \text { mobil internet servislerini kullanmayı öğrenmek benim için kolay } \\
\text { olacaktır. }\end{array}$ & $\mathrm{O}$ & O & $\bigcirc$ & $\bigcirc$ & $\bigcirc$ \\
\hline
\end{tabular}

olacaktır.

5G mobil internet servisleriyle etkileşimim açık ve anlaşılabilir olacaktır.

$\bigcirc$

O

$\mathrm{C}$

$\bigcirc$

5G mobil internet servislerinin kullanımını kolay bulacağım.

$\bigcirc$

$\mathrm{O}$

$\bigcirc$

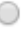

$\bigcirc$

5G mobil internet servislerinin kullanımında uzmanlașmak kolay olacaktır.

$\bigcirc$

$\bigcirc$

$\mathrm{C}$

$\bigcirc$

Benim için önemli olan insanlar $5 \mathrm{G}$ mobil internet servislerin kullanmam gerektiğini düşünüyor.

$\mathrm{O}$

$\bigcirc$

$\bigcirc$

$\bigcirc$

Davranışımı etkileyen kişiler, $5 \mathrm{G}$ mobil İnternet servislerini kullanmam gerektiğini düşünüyor.

$\bigcirc$

○

O

○

○

○ 